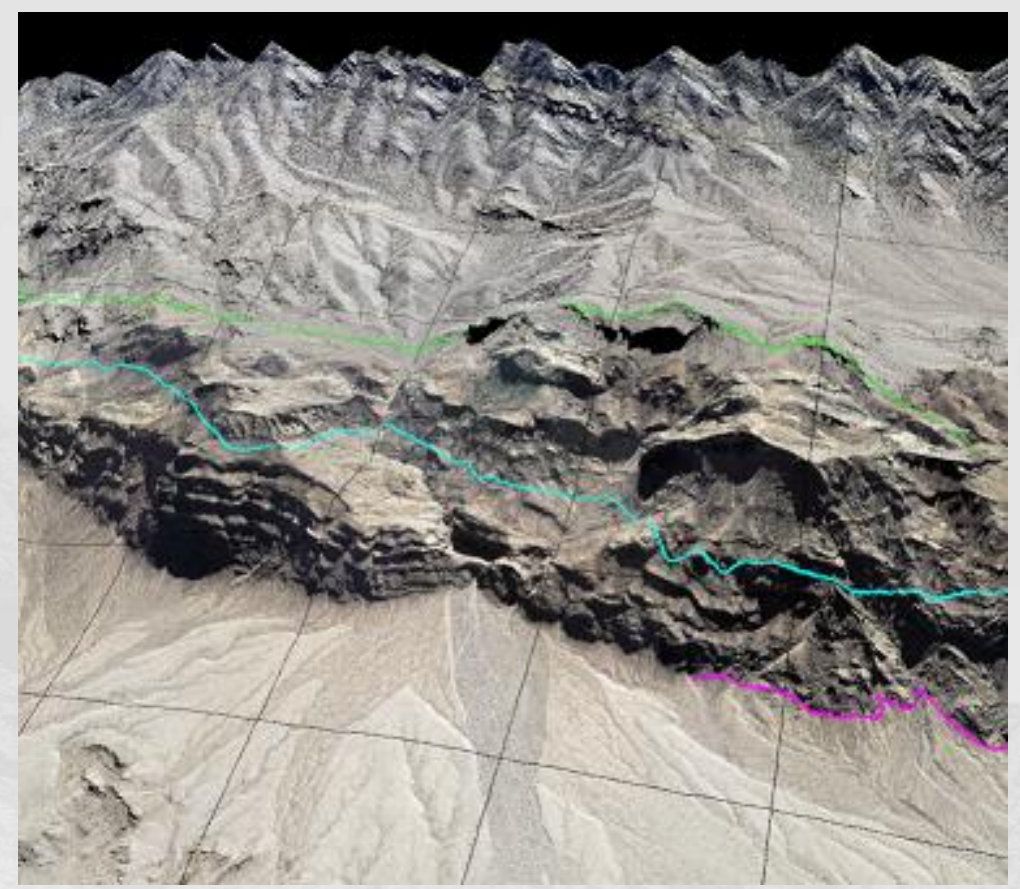

\title{
USING 3D GIS TO REVEAL EXTENSIONAL FAULT AND MEGABRECCIA GEOMETRY, WEST SIDE OF THE SHEEP RANGE, NEVADA
}

\author{
Professor Peter L. Guth \\ Department of Oceanography \\ United States Naval Academy \\ Annapolis MD, USA \\ pguth@usna.edu
}

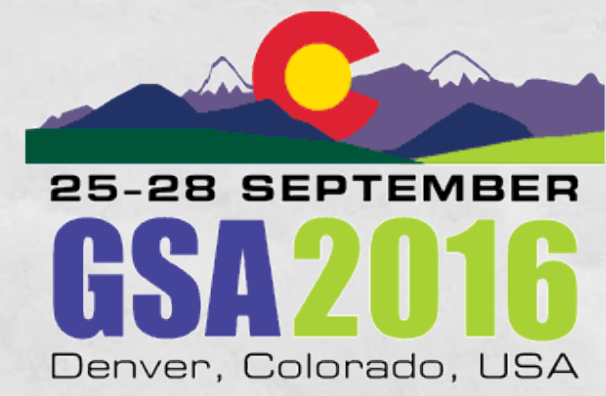




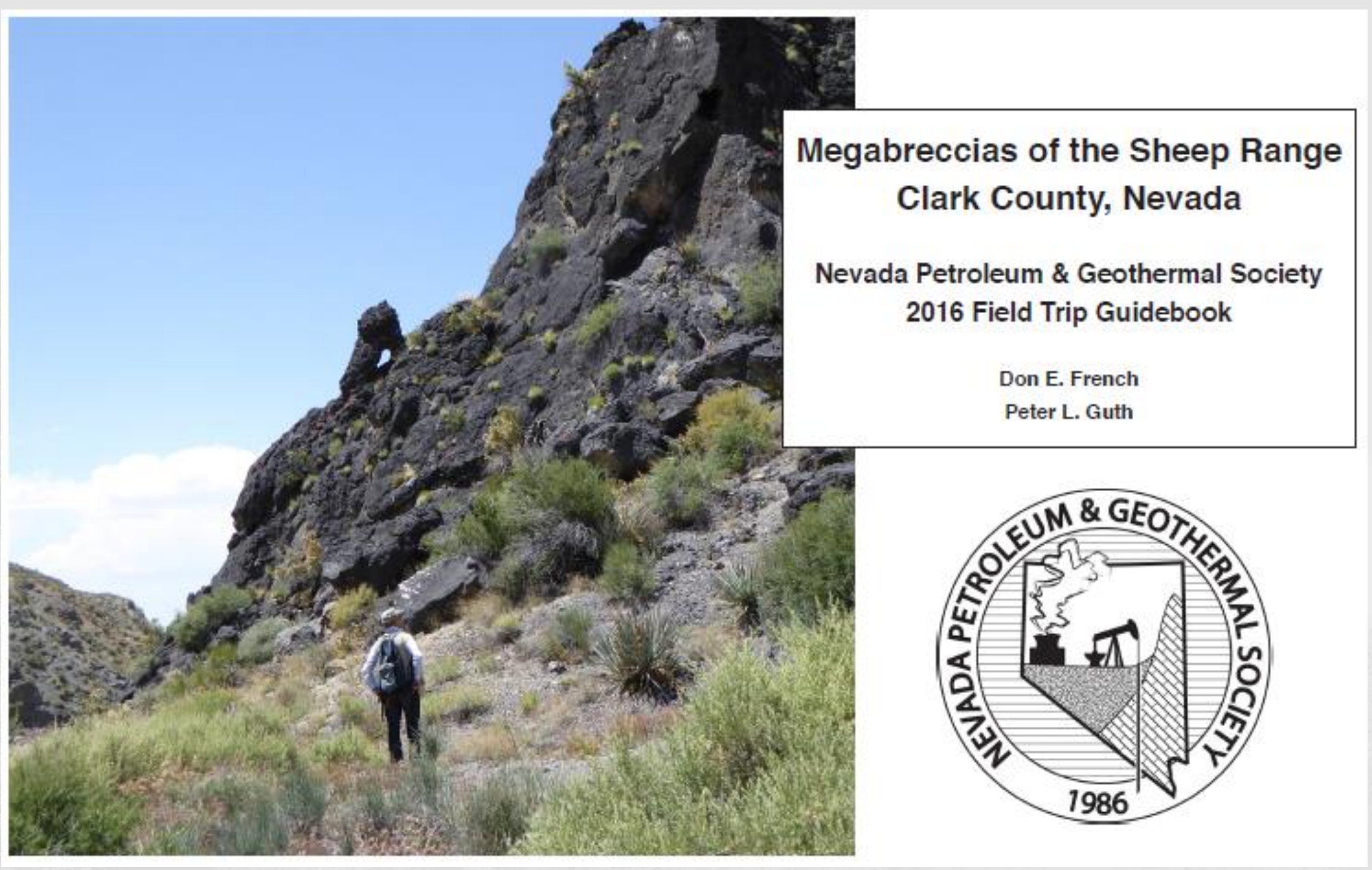

- New look at old data 


\section{Field Mapping-Pre GIS, Pre DEMs}

- 1977-1979, PhD Mapping

- 1984-1987, unpublished mapping

- GSAB paper, 3 field trip guidebooks

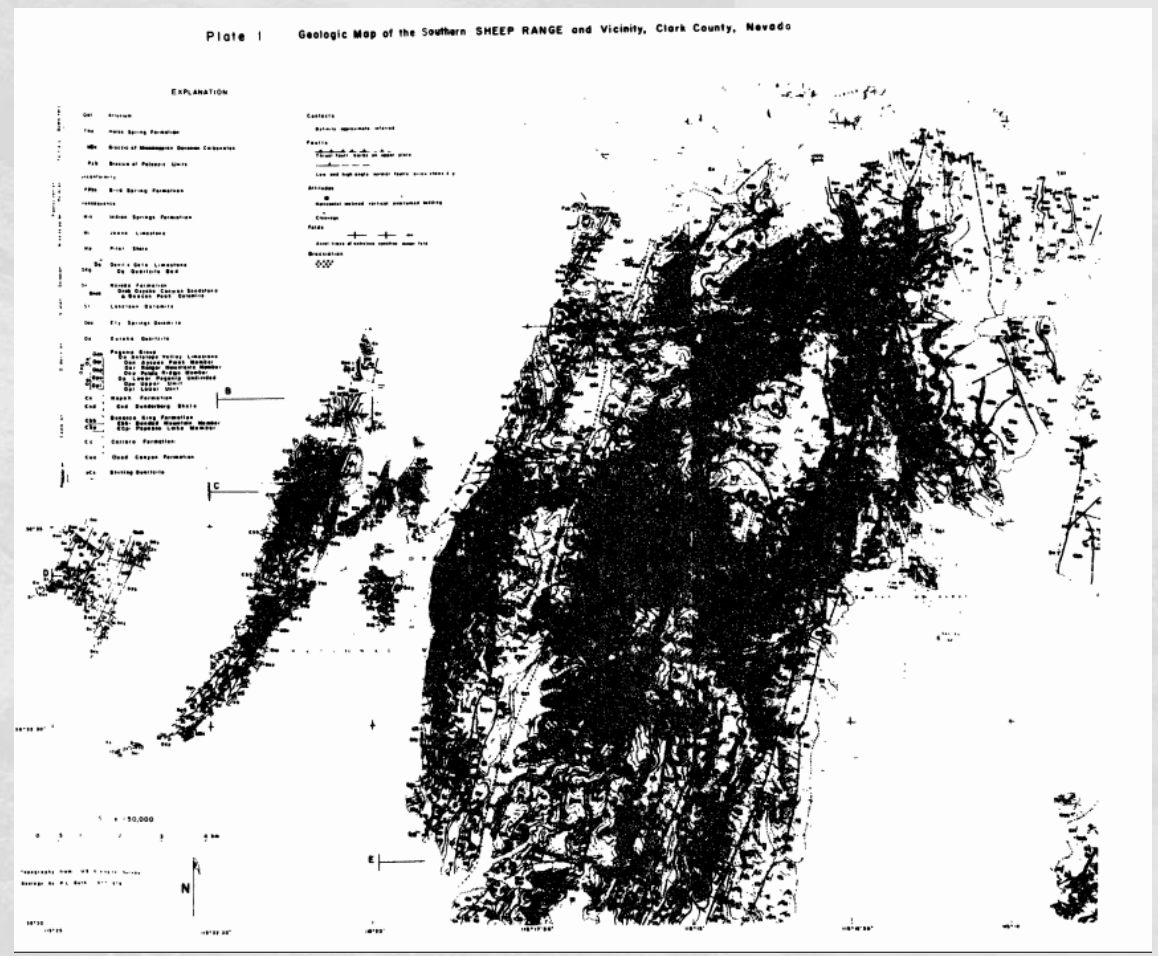

Guth, 1980 (illegible mess)

Guth, 1986 (KMZ online)

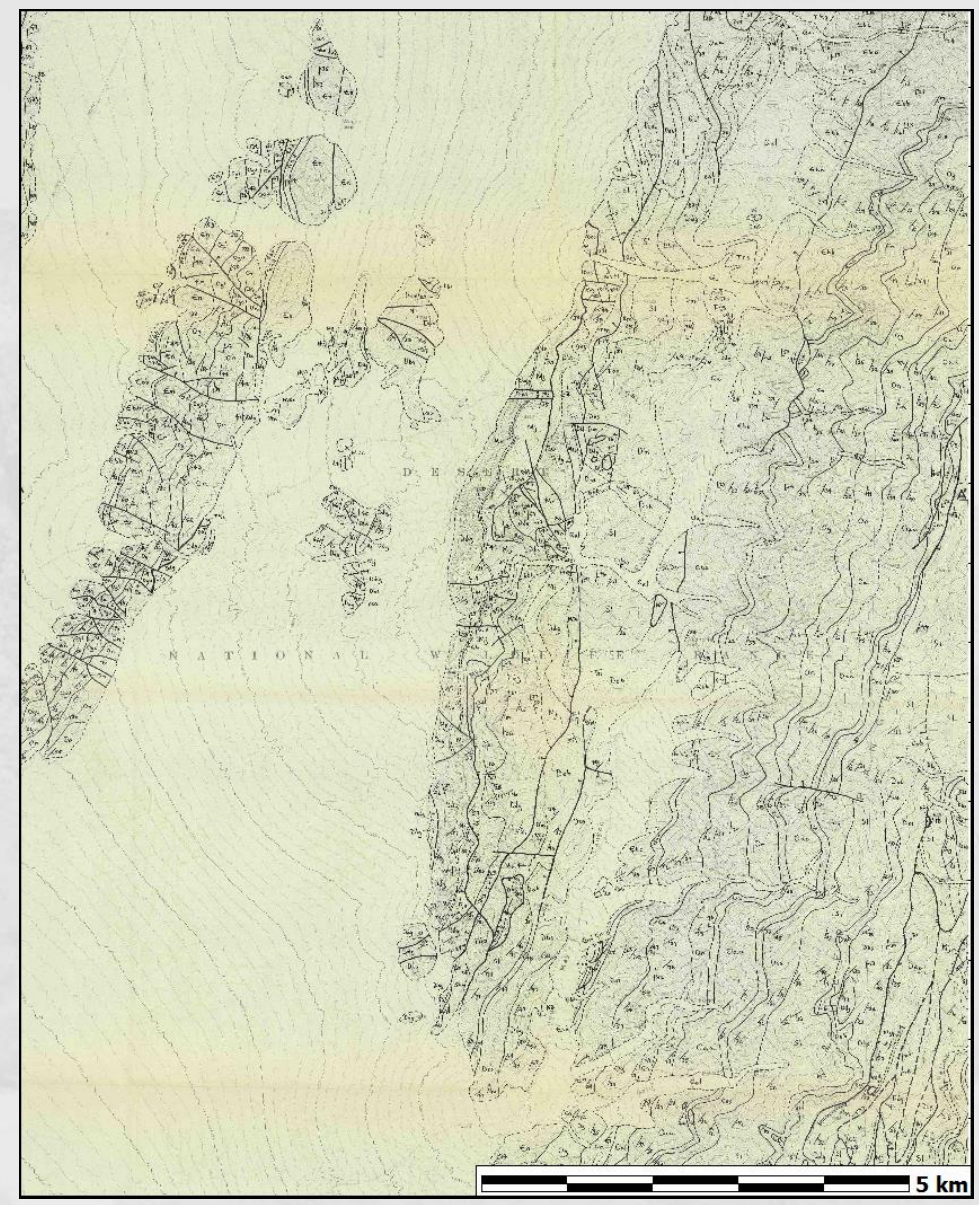




\section{Photos, for 1:62.5K Quads}
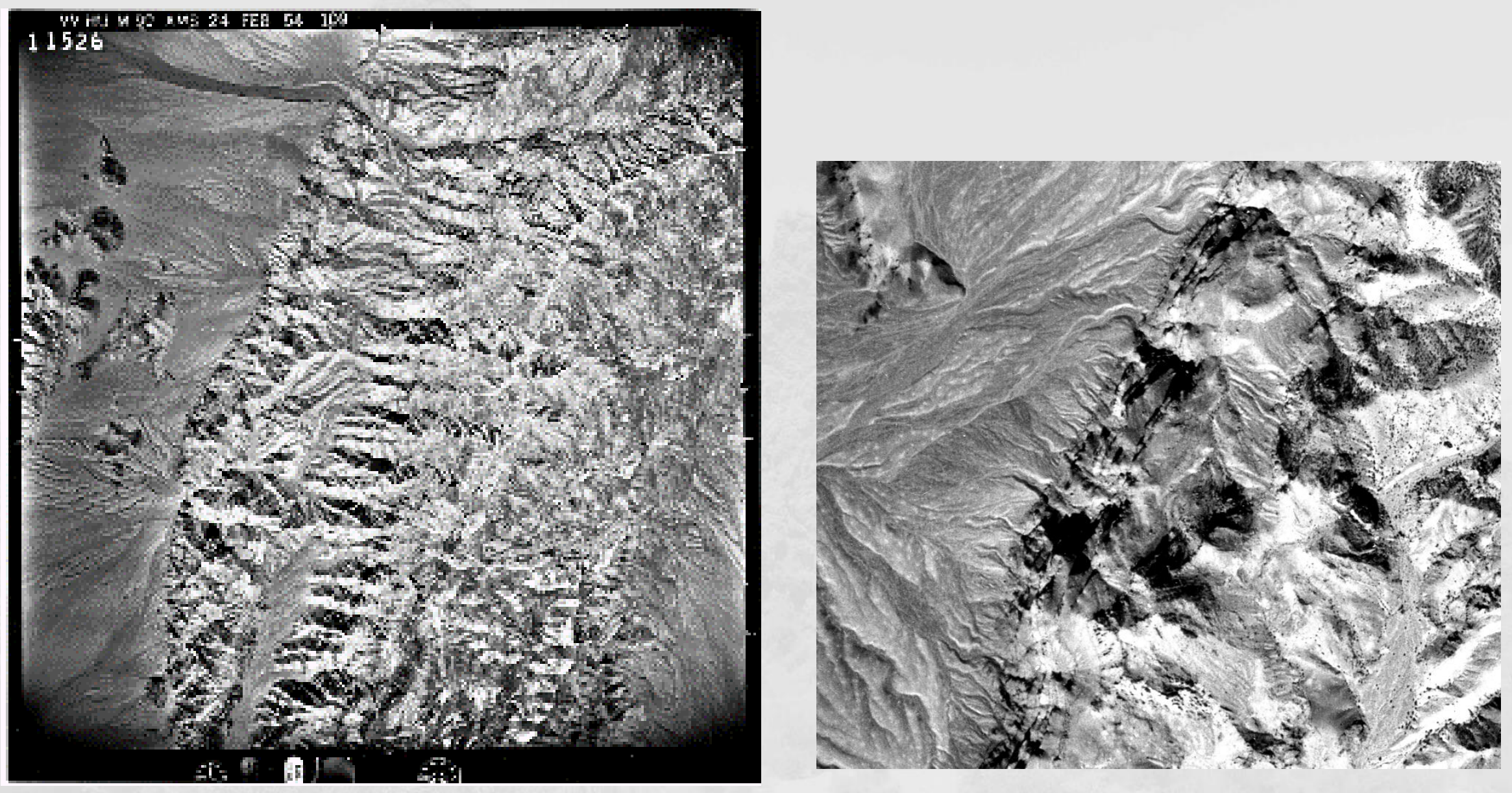

600 dpi scans, full resolution

Not free, then or now 


\section{Photos for 1:24K Quads}
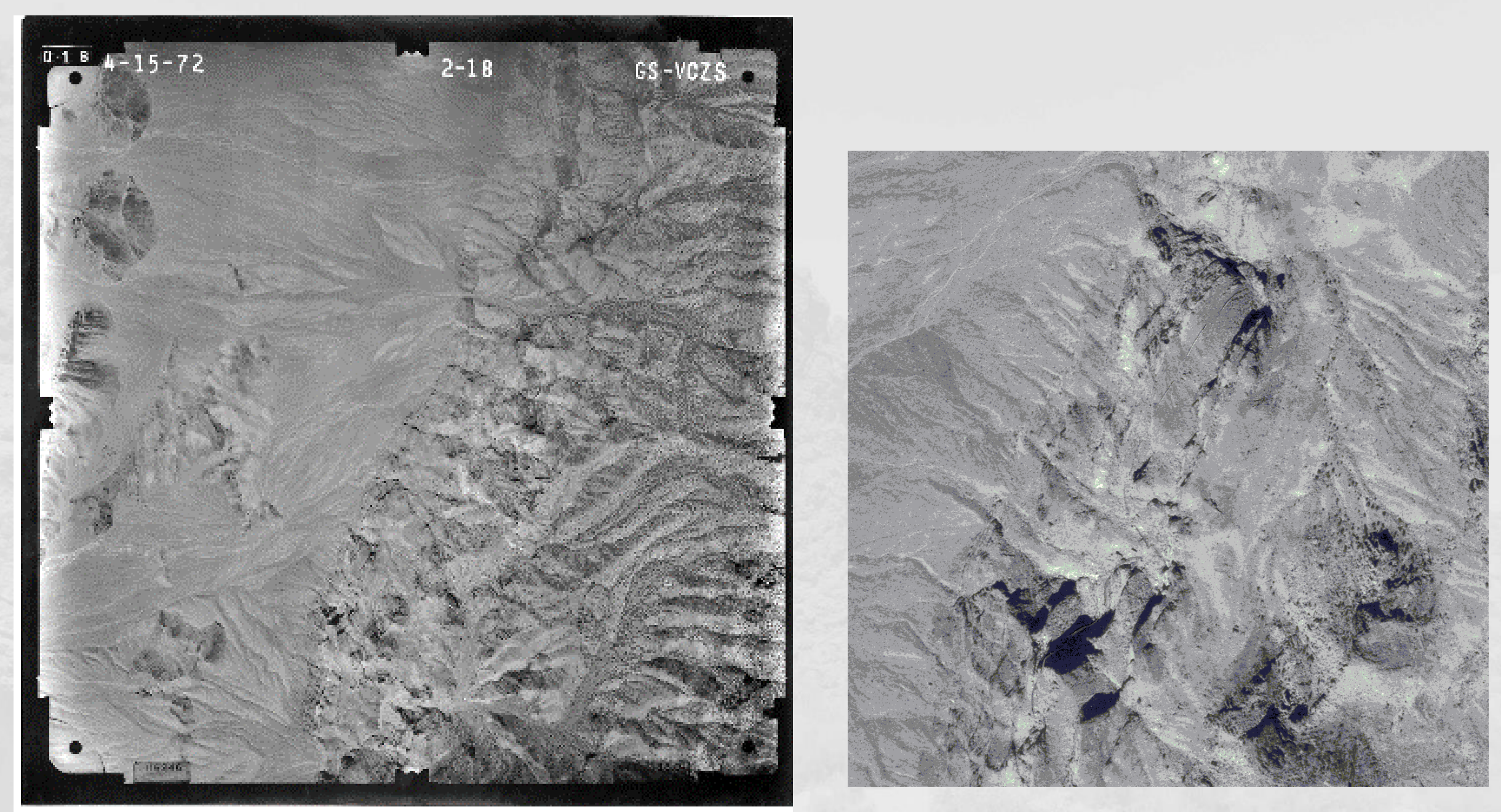

Not free, then or now 


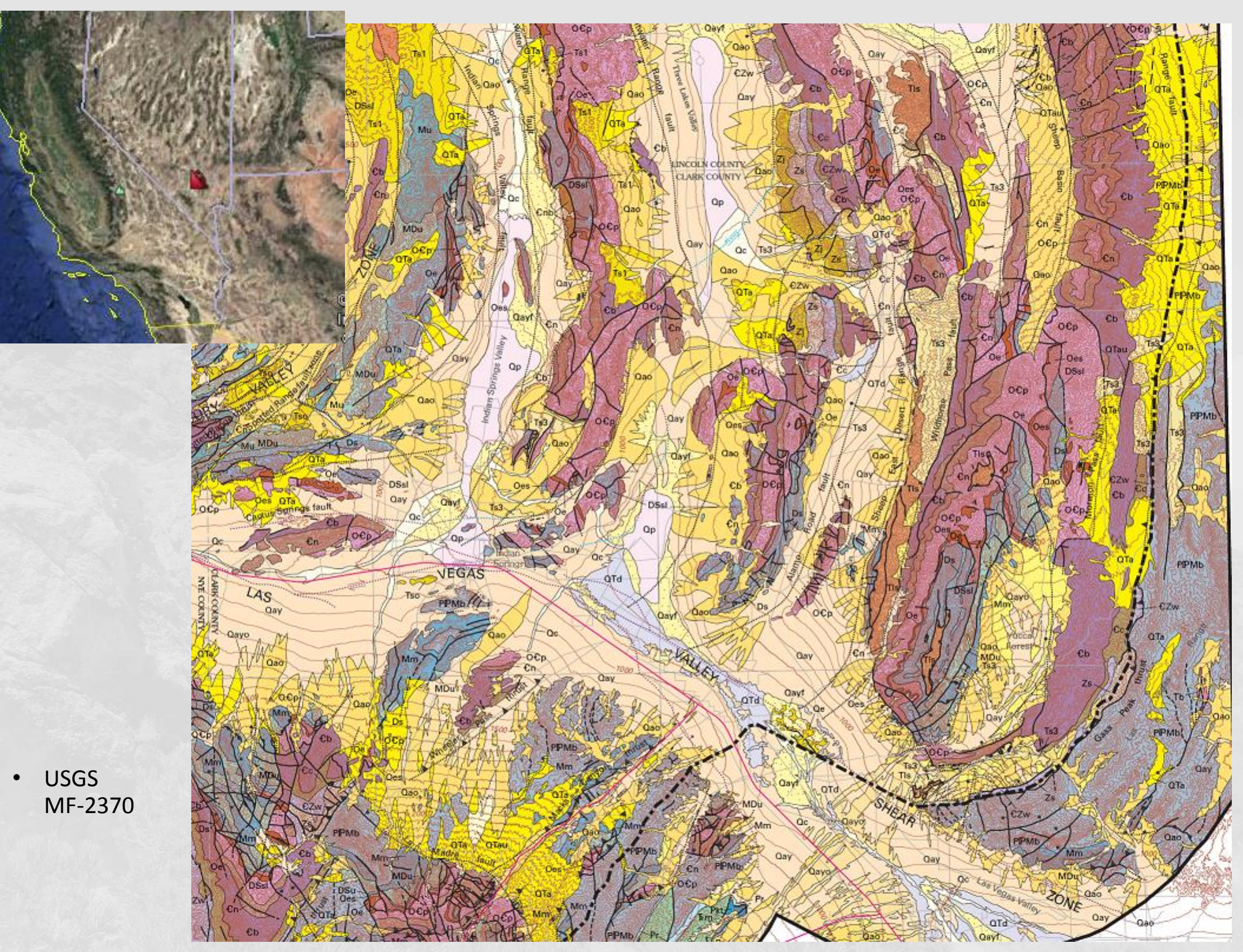




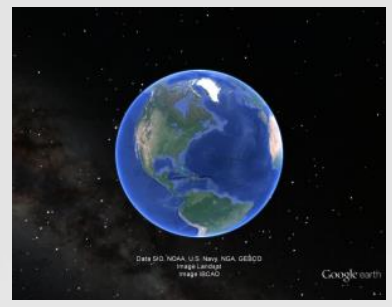

\section{GIS}

- Map based, visual

- Interactive analysis

- Common data formats

- Rasters in Geotiff

or $\mathrm{KML} / \mathrm{KMZ}$

- Vectors in shapefile or $\mathrm{KML} / \mathrm{KMZ}$

- Easily use multiple programs

\section{Google Earth}

- Simplicity

- Cost (some license restrictions)

- Digitize

- Display

- Not analysis 


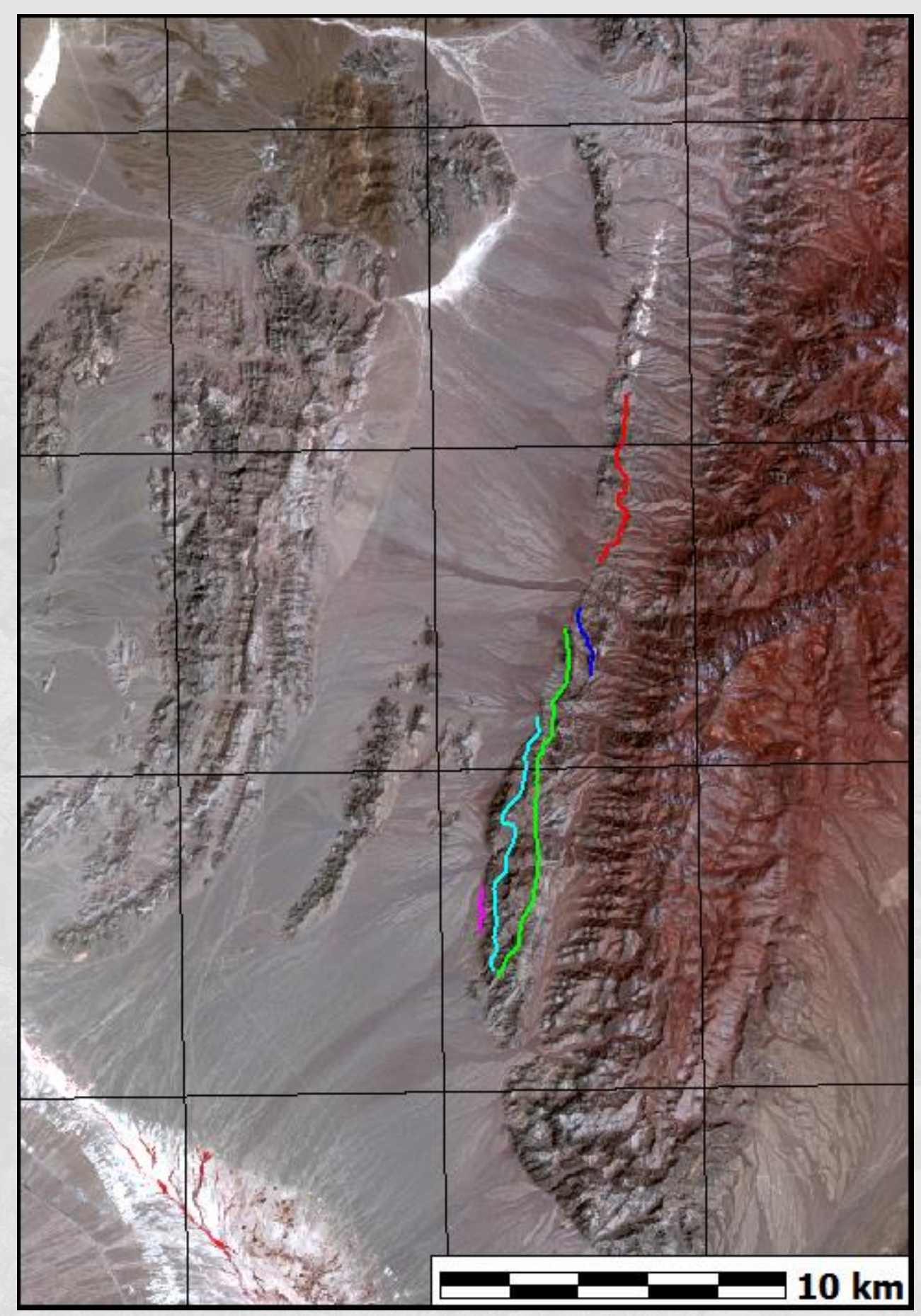

- Digitized from 1:24K maps (scan mylars)

- Limited photo revision (continuing)

- $5 \times 28 \mathrm{~km}$

- All bedrock to south

- Mostly lake to north

- Pine Canyon Fault
- Deadman Canyon Fault
— Wagon Canyon Fault
- Rye Patch Fault
— Corral Canyon Fault




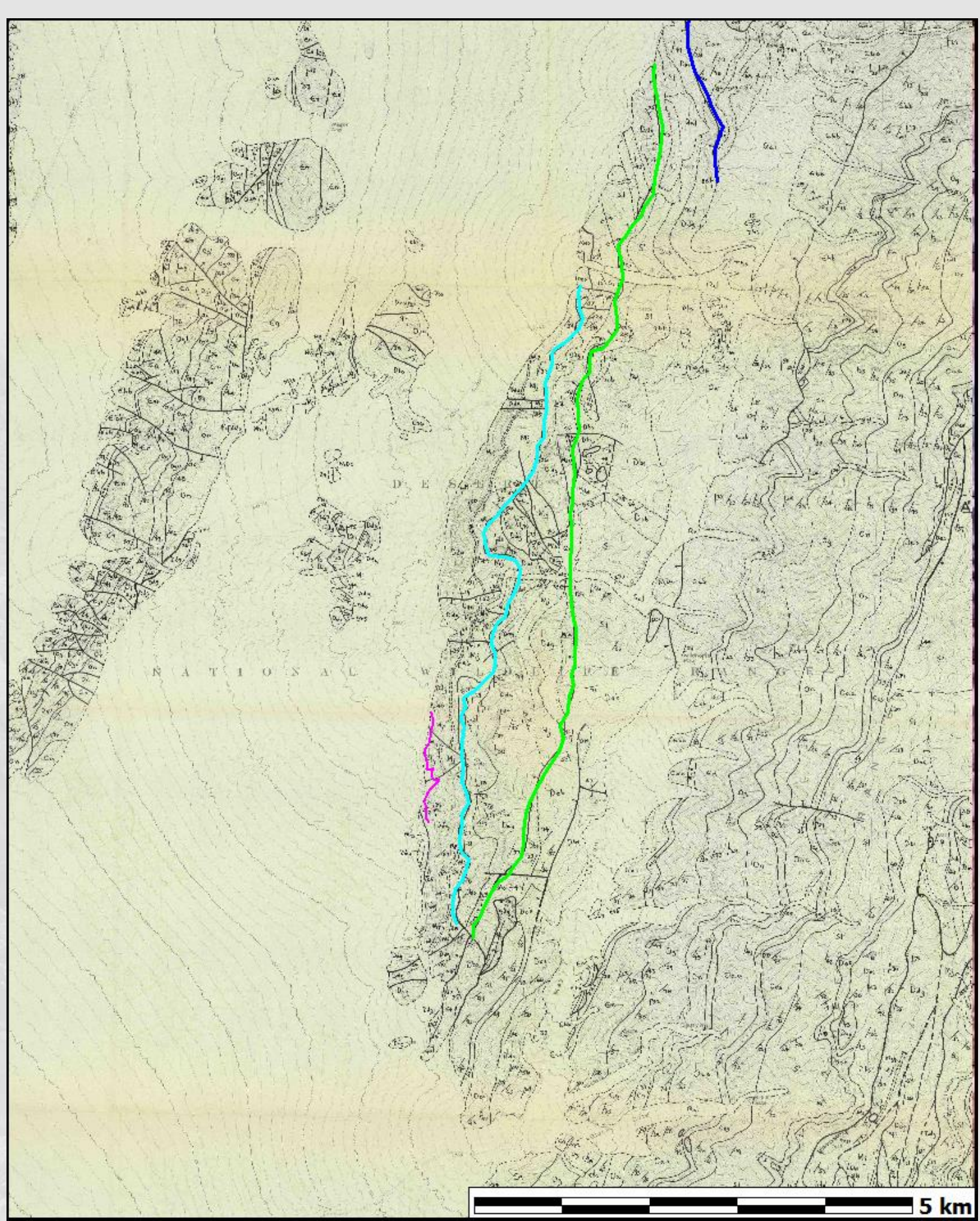

- Pine Canyon Fault

- Deadman Canyon Fault

- Wagon Canyon Fault

- Rye Patch Fault

- Corral Canyon Fault 


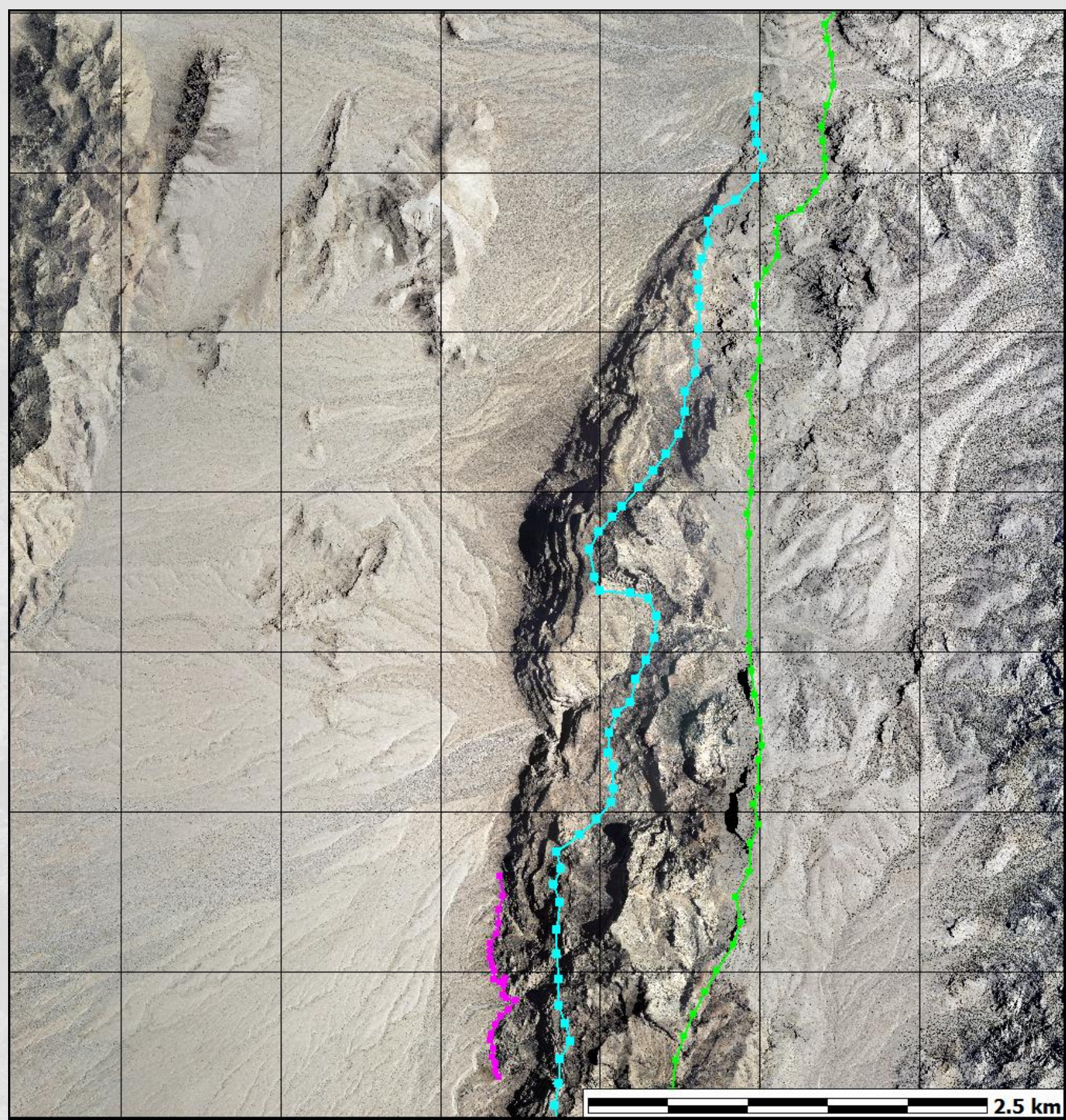

- Points

- Lines 


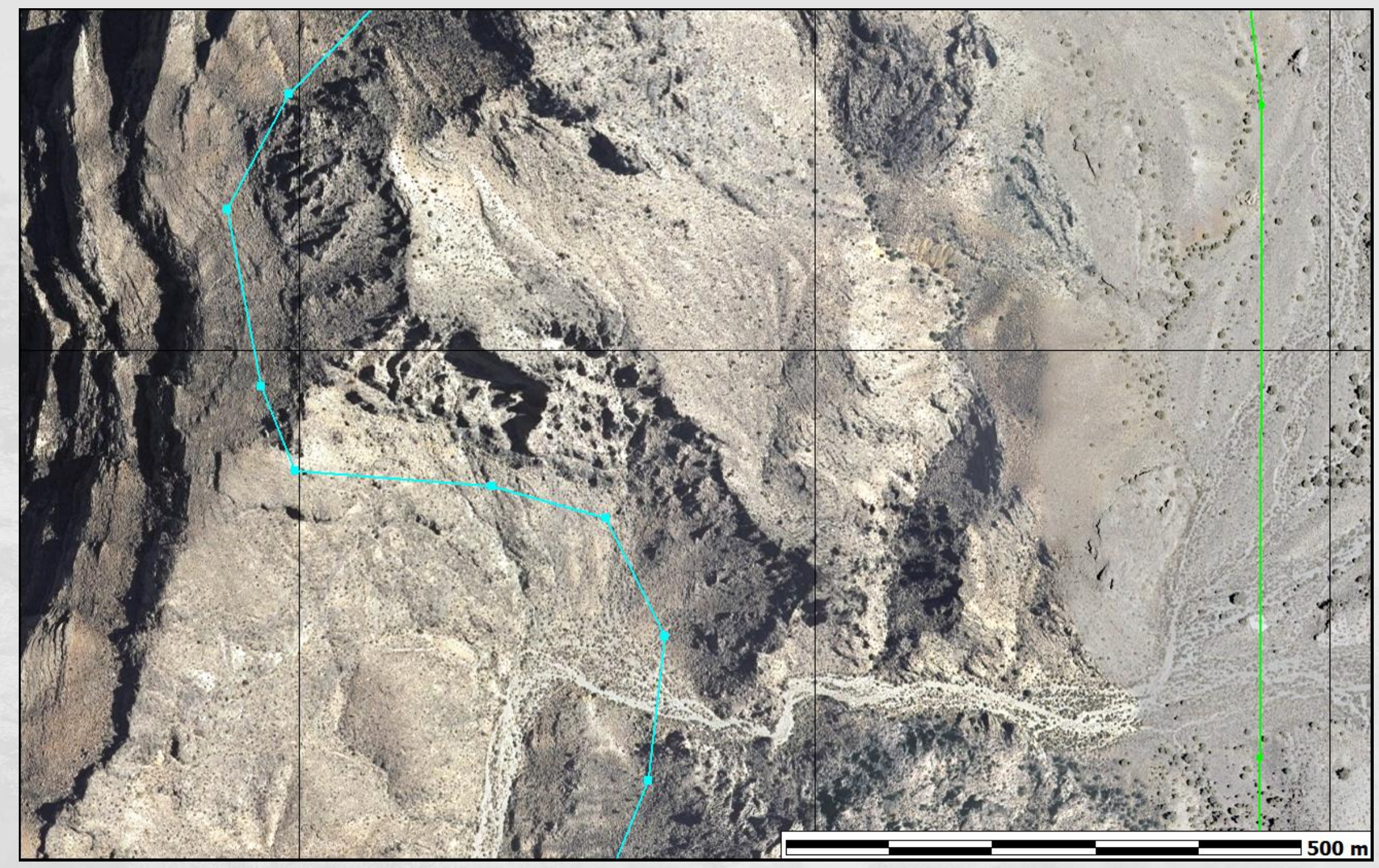

- $1 \mathrm{~m}$ photo resolution 


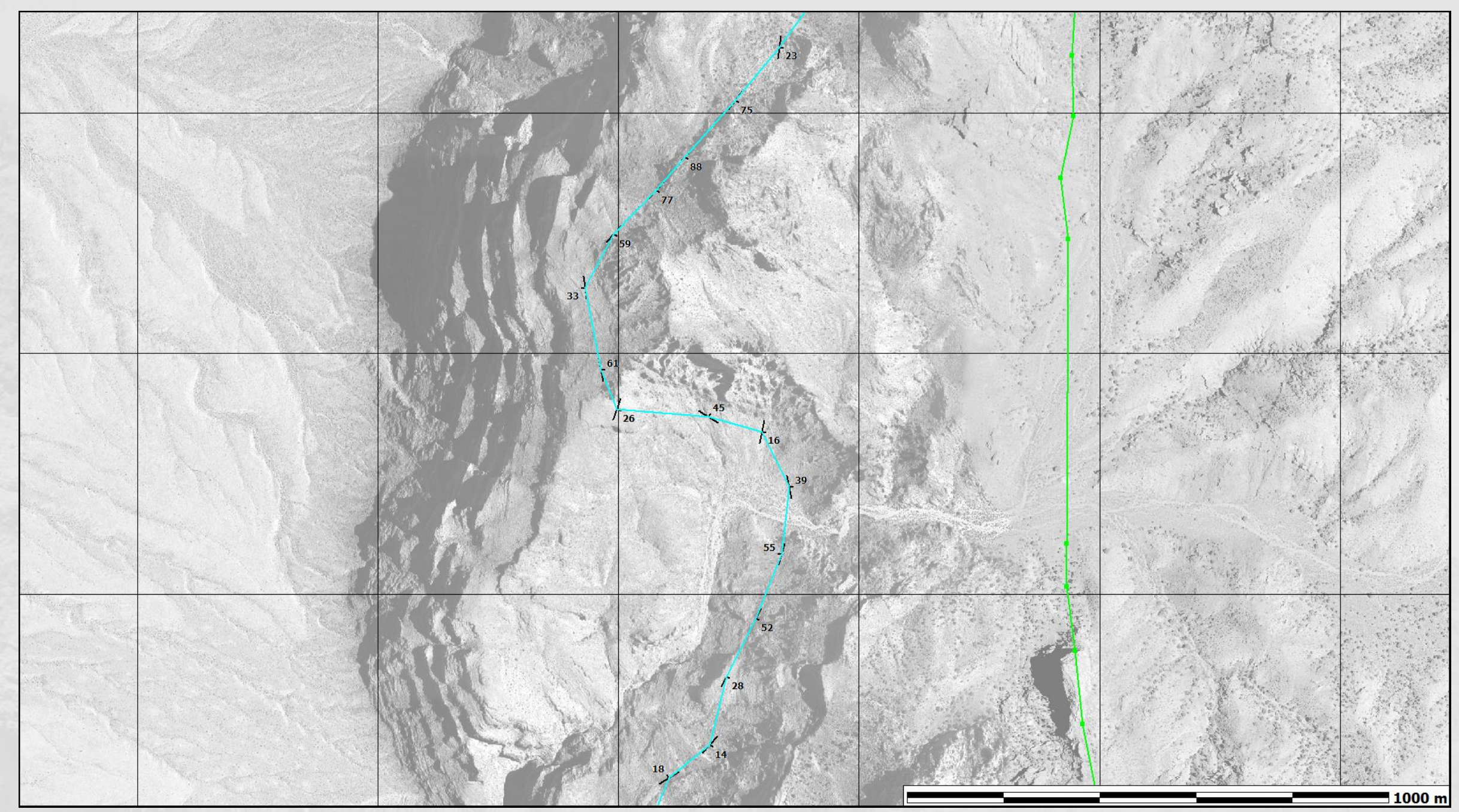

- Sequential three point problems along contact 

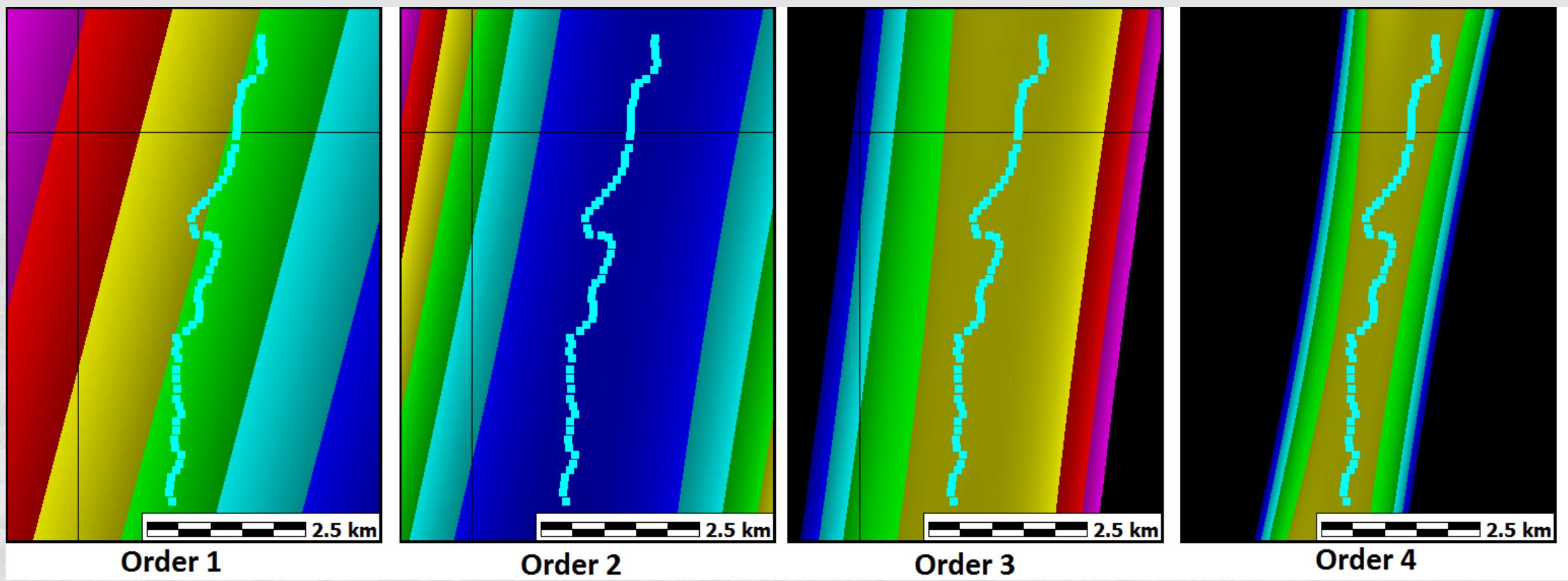

- Trend surface, best fit to all points along profile

- Narrow elevation range for fault trace

- Inflection points in higher order surfaces mostly parallel fault trace

- Deviations grid can be used for parallel planes (formation boundaries) 


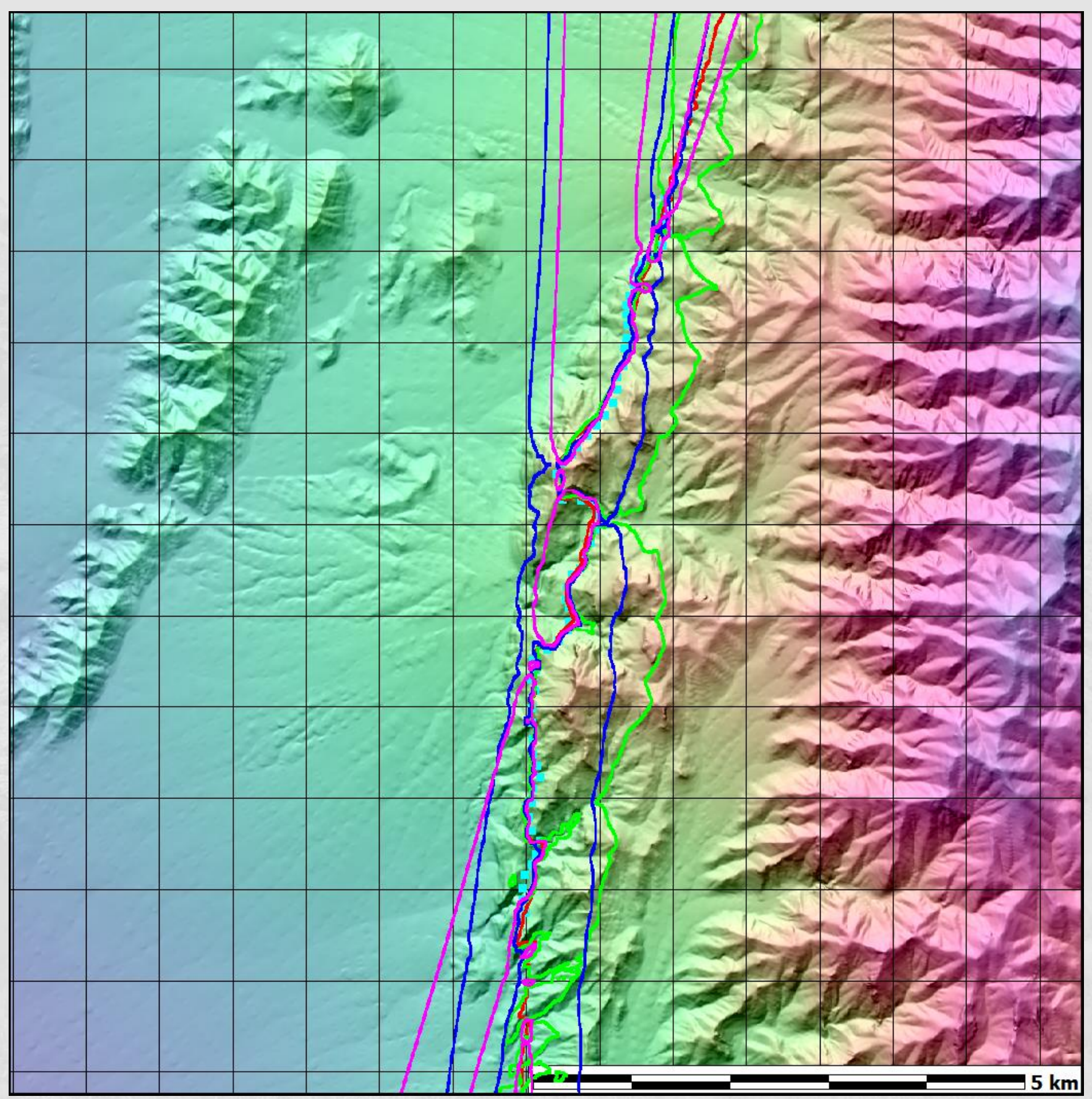




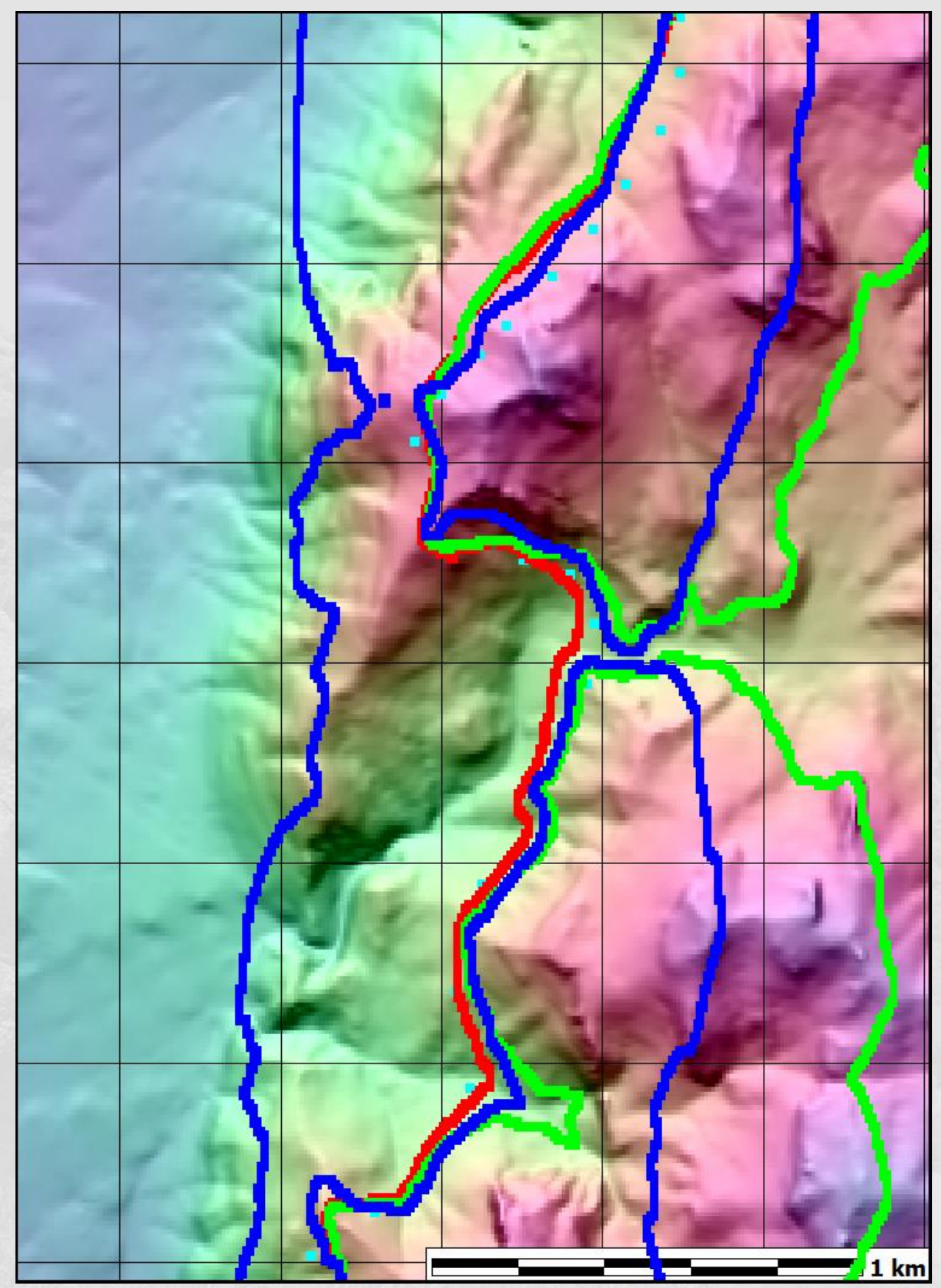

\section{Trend surfaces}

- Order 1 (best?)

- Order 2

- Order 3 


\section{Table 1. Major fault blocks, Hoodoo Hills Havoc}

\begin{tabular}{|c|c|c|c|c|}
\hline Fault & Long & $\begin{array}{l}\text { Fault } \\
\text { trend }\end{array}$ & Age of upper plate & Notes \\
\hline $\begin{array}{l}\text { Pine Canyon Fault } \\
\text { (?) }\end{array}$ & $9 \mathrm{~km}$ & $\begin{array}{l}\text { N23E } \\
5 N W\end{array}$ & Ordovician to Silurian & $\begin{array}{l}\text { Limited ground } \\
\text { control, and may be } \\
\text { part of the Deadman } \\
\text { Canyon block }\end{array}$ \\
\hline $\begin{array}{l}\text { Deadman Canyon } \\
\text { Fault }\end{array}$ & $5 \mathrm{~km}$ & $\begin{array}{l}\text { N50E } \\
8 N W\end{array}$ & Ordovician to Silurian & \\
\hline $\begin{array}{l}\text { Wagon Canyon } \\
\text { Fault }\end{array}$ & $\begin{array}{l}11 \\
\mathrm{~km}\end{array}$ & N9E $20 W$ & $\begin{array}{l}\text { Ordovician to lower } \\
\text { Devonian }\end{array}$ & $\begin{array}{l}\text { Correlated with Cow } \\
\text { Camp Road Fault }\end{array}$ \\
\hline Rye Patch Fault & $8 \mathrm{~km}$ & N14E 24E & $\begin{array}{l}\text { Ordovician to } \\
\text { Mississippian }\end{array}$ & $\begin{array}{l}\text { Correlated with } \\
\text { Black Hills Gap fault }\end{array}$ \\
\hline $\begin{array}{l}\text { Corral Canyon } \\
\text { Fault }\end{array}$ & $2 \mathrm{~km}$ & $\begin{array}{l}\text { N11W } \\
17 \mathrm{~W}\end{array}$ & Devonian-Mississippian & \\
\hline $\begin{array}{l}\text { Bedrock or } \\
\text { unexposed fault }\end{array}$ & & & Devonian-Mississippian & \\
\hline
\end{tabular}

Low angle, intial movement to west, some rotated back to east 


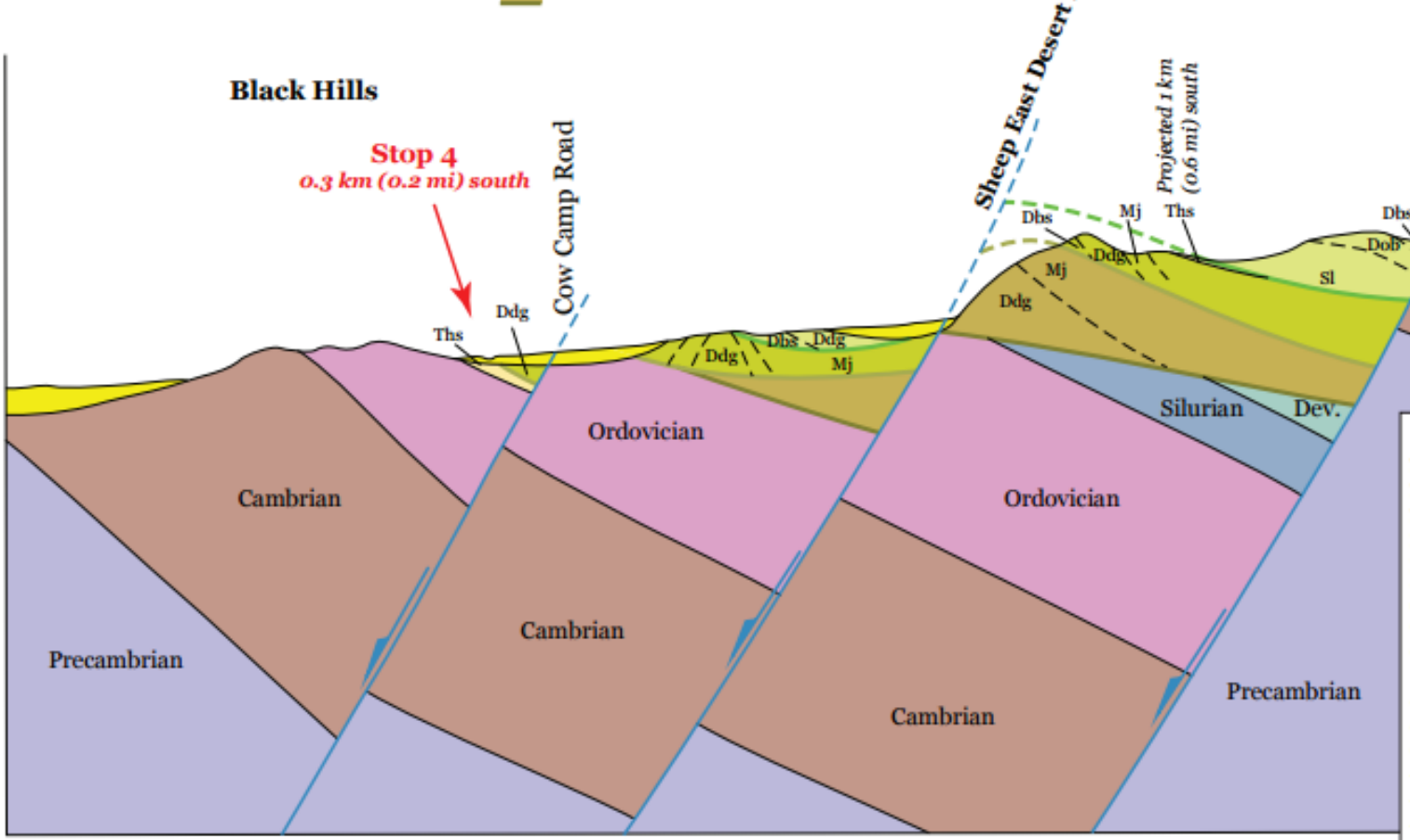

Figure 4-2. East-west cross section through the Black Hills and Sheep Range. Megabreccia relationships and internal deformation are more complex that shown here.

Picture Canyon

Projected $5 \mathrm{~km}(3 \mathrm{mi})$ north

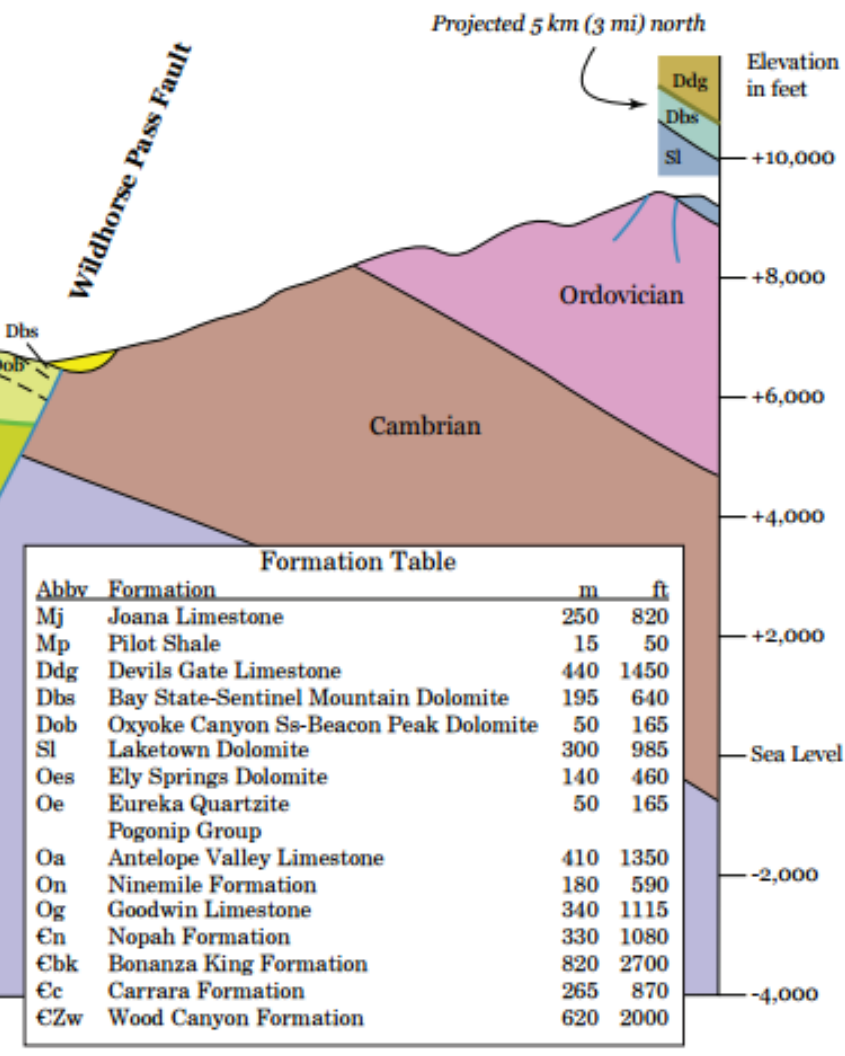

(after Guth, 1986)

\section{- Down to west motion}

- Crossing higher angle faults

- Later rotation of faults to the east 


\section{Compare}

Table 2. Selected megabreccia deposits, western Great Basin

\begin{tabular}{|c|c|c|c|c|c|}
\hline Location & $\begin{array}{l}\text { Extent, length } x \\
\text { width }\end{array}$ & Vertical drop & $\begin{array}{l}\text { Slide } \\
\text { Thickness }\end{array}$ & Age & References \\
\hline Blackhawk & $8 \mathrm{~km} \times 3.2 \mathrm{~km}$ & $\sim 1200 \mathrm{~m}$ & $10-30 \mathrm{~m}$ & 6.5-31 k.y. & $\begin{array}{l}\text { Shreve, } 1968 \\
\text { Nichols and others, } 2006\end{array}$ \\
\hline $\begin{array}{l}\text { Eureka } \\
\text { Valley }\end{array}$ & $1.7 \mathrm{~km} \times 0.4 \mathrm{~km}$ & $\sim 700 \mathrm{~m}$ & $20 \mathrm{~m}$ & $8.2-9.5$ k.y. & $\begin{array}{l}\text { Wrucke and Corbett, } 1990 \\
\text { Watkins and others, } 2012 \\
\text { Watkins and others, } 2015\end{array}$ \\
\hline $\begin{array}{l}\text { Tin } \\
\text { Mountain } \\
\text { (4 scars) } \\
\end{array}$ & $\begin{array}{l}\text { Overall } 4 \mathrm{~km} \mathrm{x} \\
8.5 \mathrm{~km}\end{array}$ & $900-1100 \mathrm{~m}$ & $40-120 \mathrm{~m}$ & & Burchfiel, 1966 \\
\hline $\begin{array}{l}\text { Sheep } \\
\text { Range } \\
\text { (at least } 5 \\
\text { blocks) }\end{array}$ & $\begin{array}{l}\text { Overall } 5 \mathrm{~km} \times 28 \\
\mathrm{~km} \text {; individual } \\
\text { blocks to } \sim 10 \mathrm{~km} \\
\text { wide }\end{array}$ & $\begin{array}{l}\text { 1000-3000 m } \\
\text { (?); depends on } \\
\text { bedding dip at } \\
\text { time, and } \\
\text { position along } \\
\text { strike }\end{array}$ & & Miocene (?) & \\
\hline
\end{tabular}


Tin Mountain, 1/3" ( 10 m) 3DEP

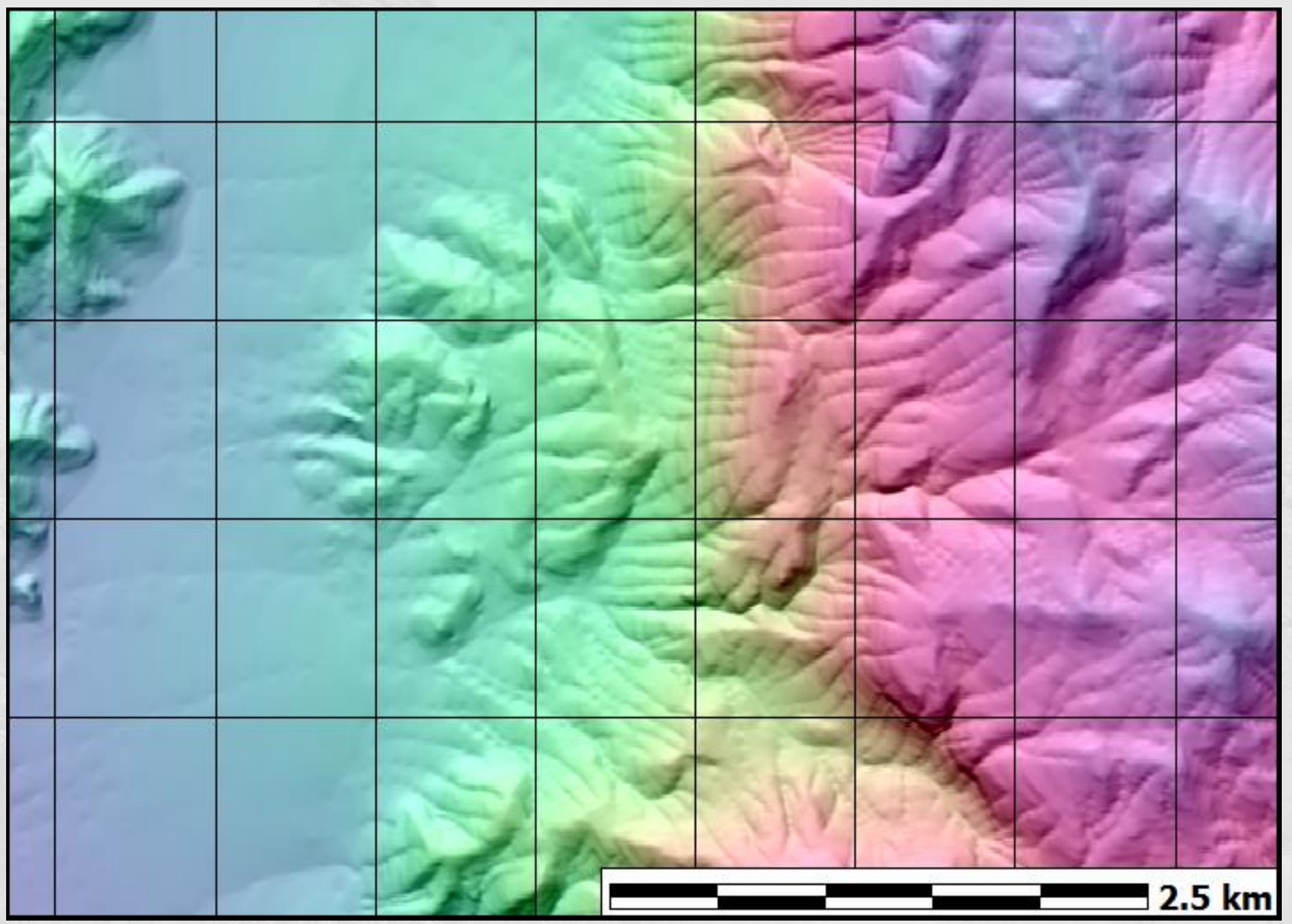




\section{Tin Mountain, 2 m lidar with 1/3" 3DEP hole fill along edges}

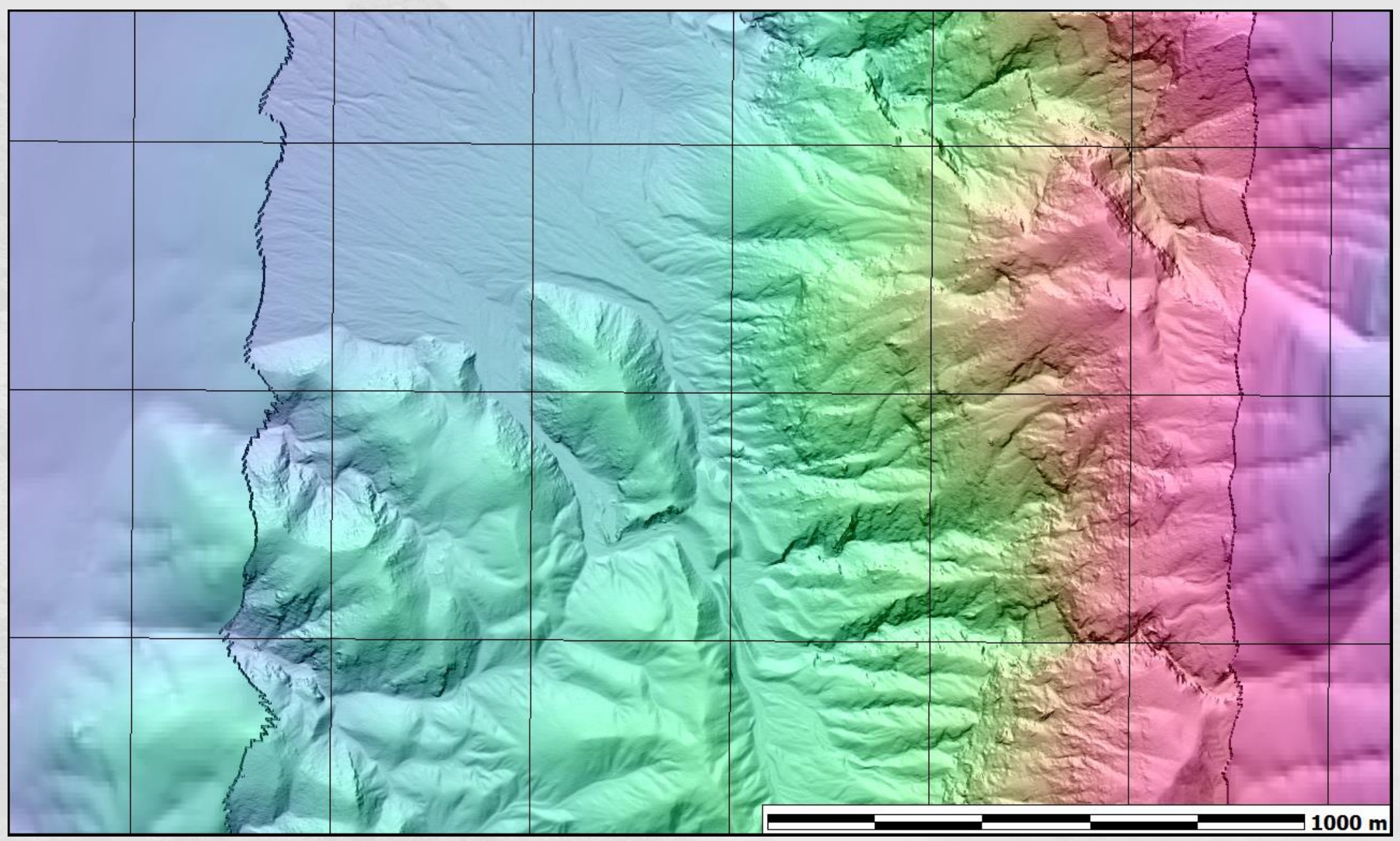

- Vertical datum shift, left in to highlight quality change 


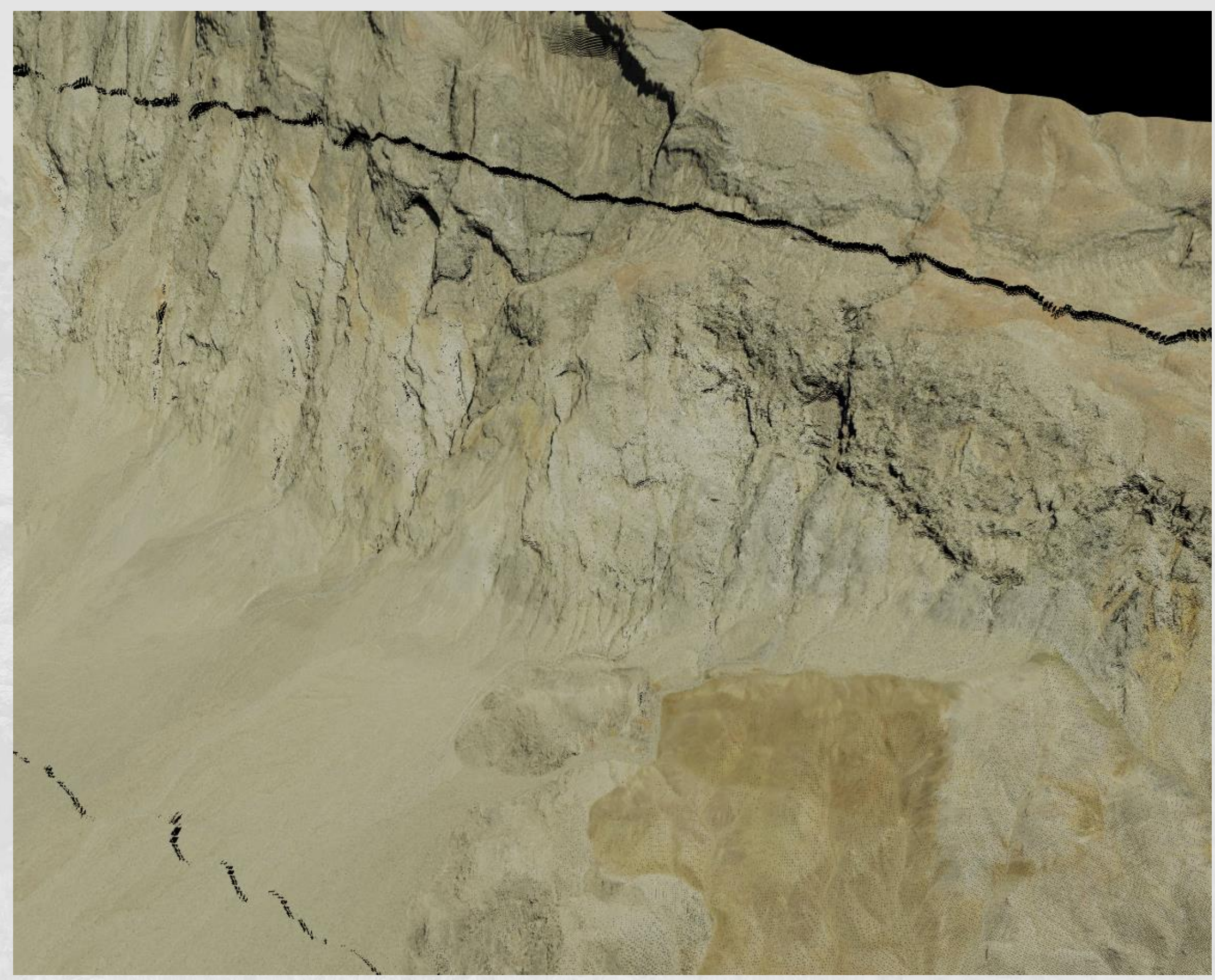




\section{Eureka Valley Landslide (Wrucke and corbett, 1990)}

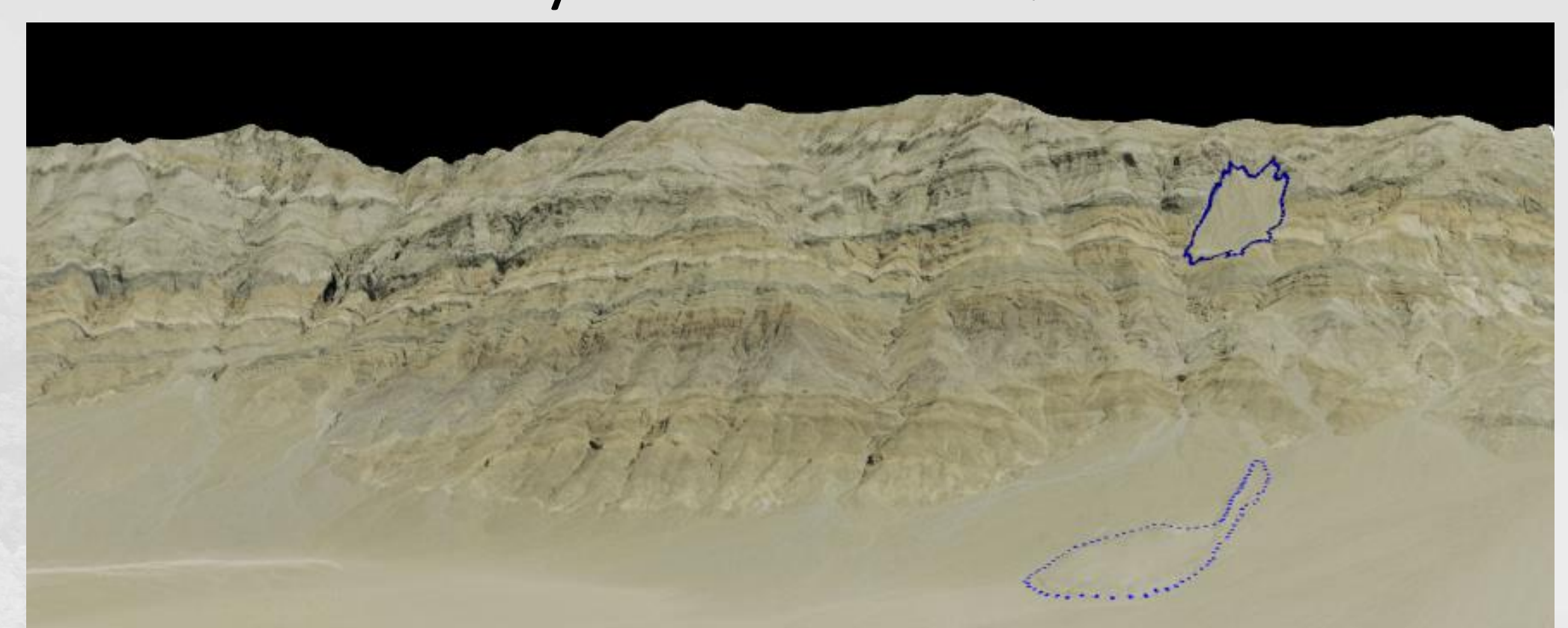




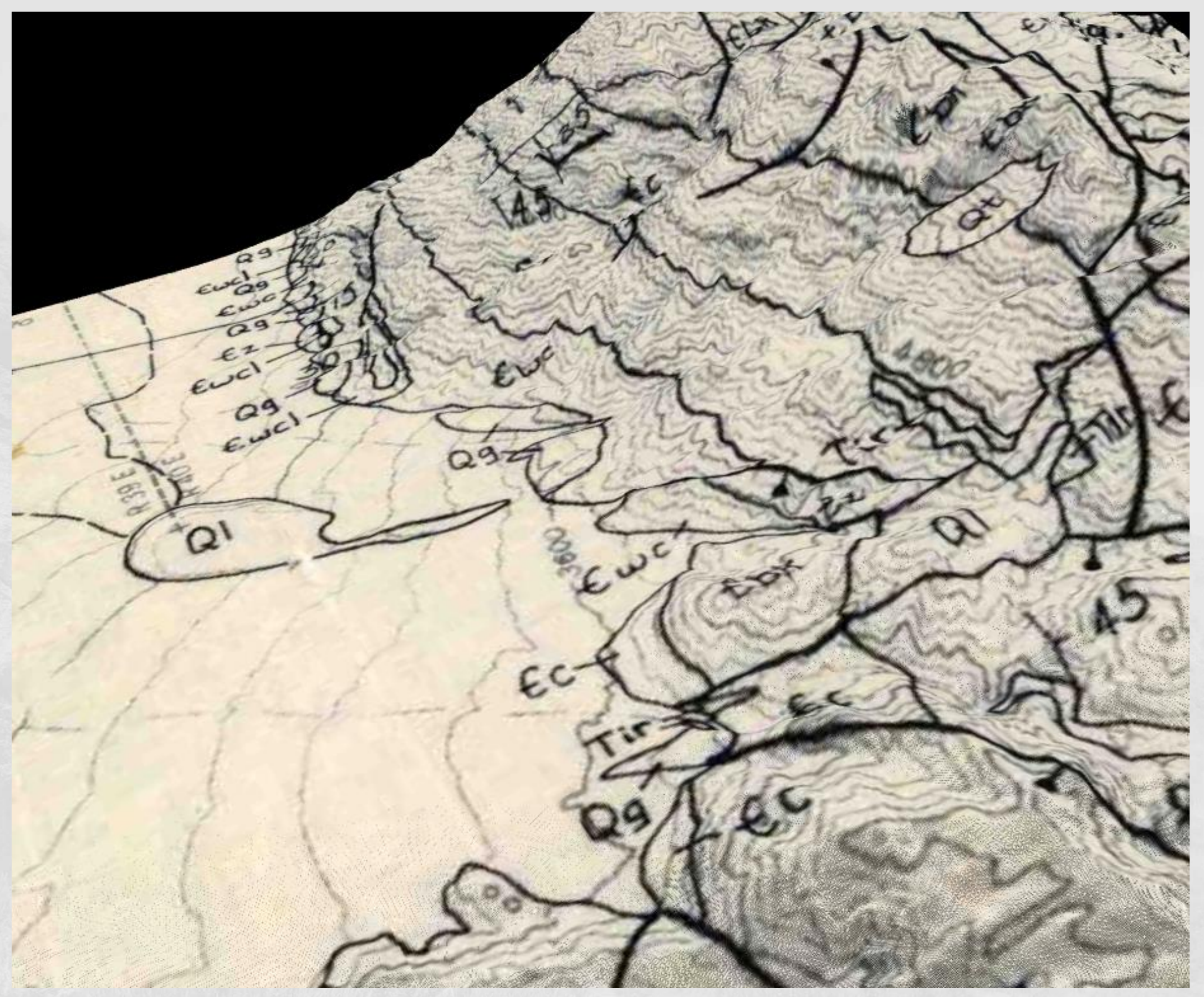




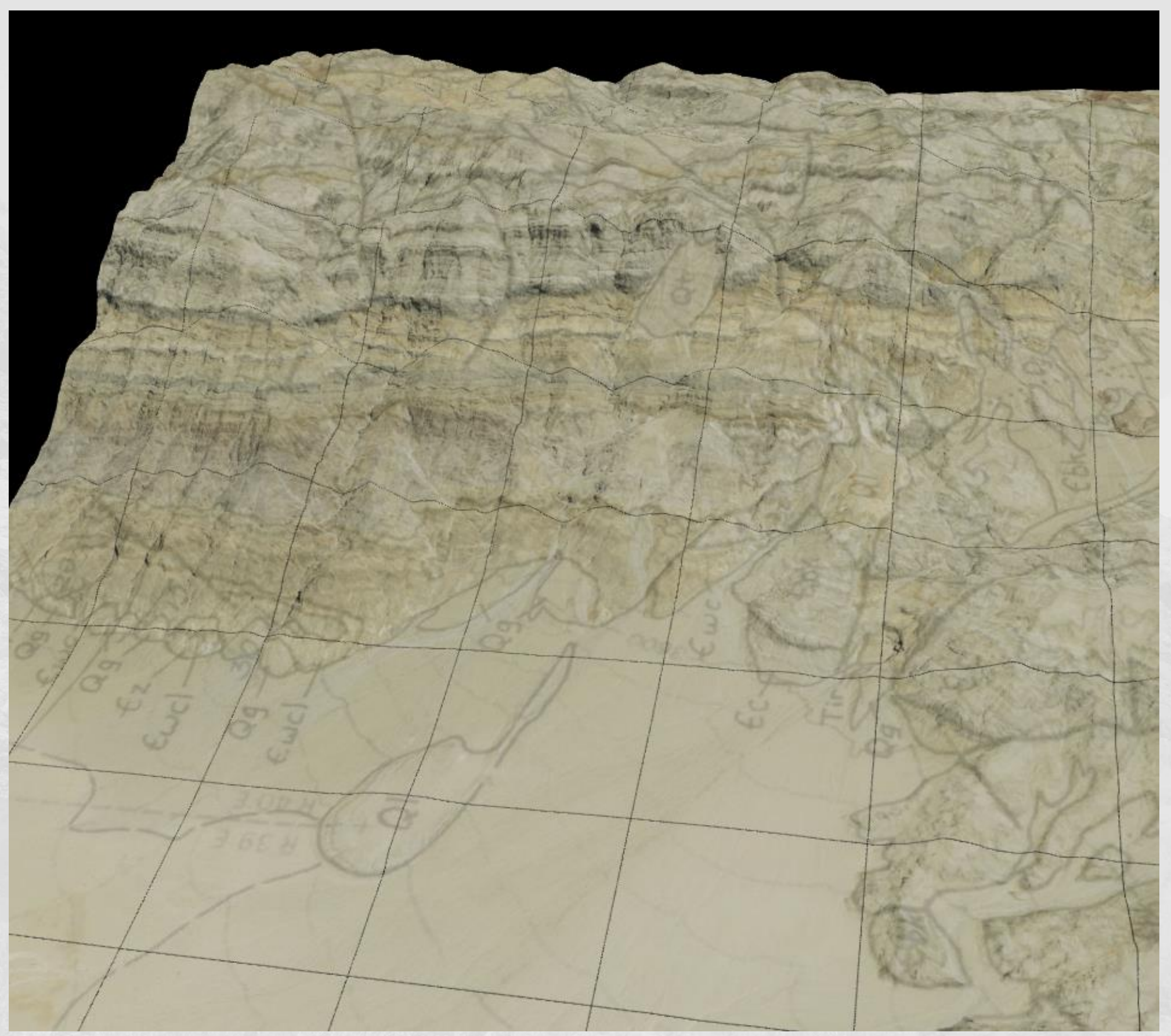


Planar Trend Surface from map/imagery and $1 / 3$ " 3DEP

- Talus, geologic quad, N25E 29NW (55.87\% slope)

- Talus, 1 m imagery: N27E 29NW (55.12\% slope)

- Slide block, N57E 5NW (8.77\% slope)

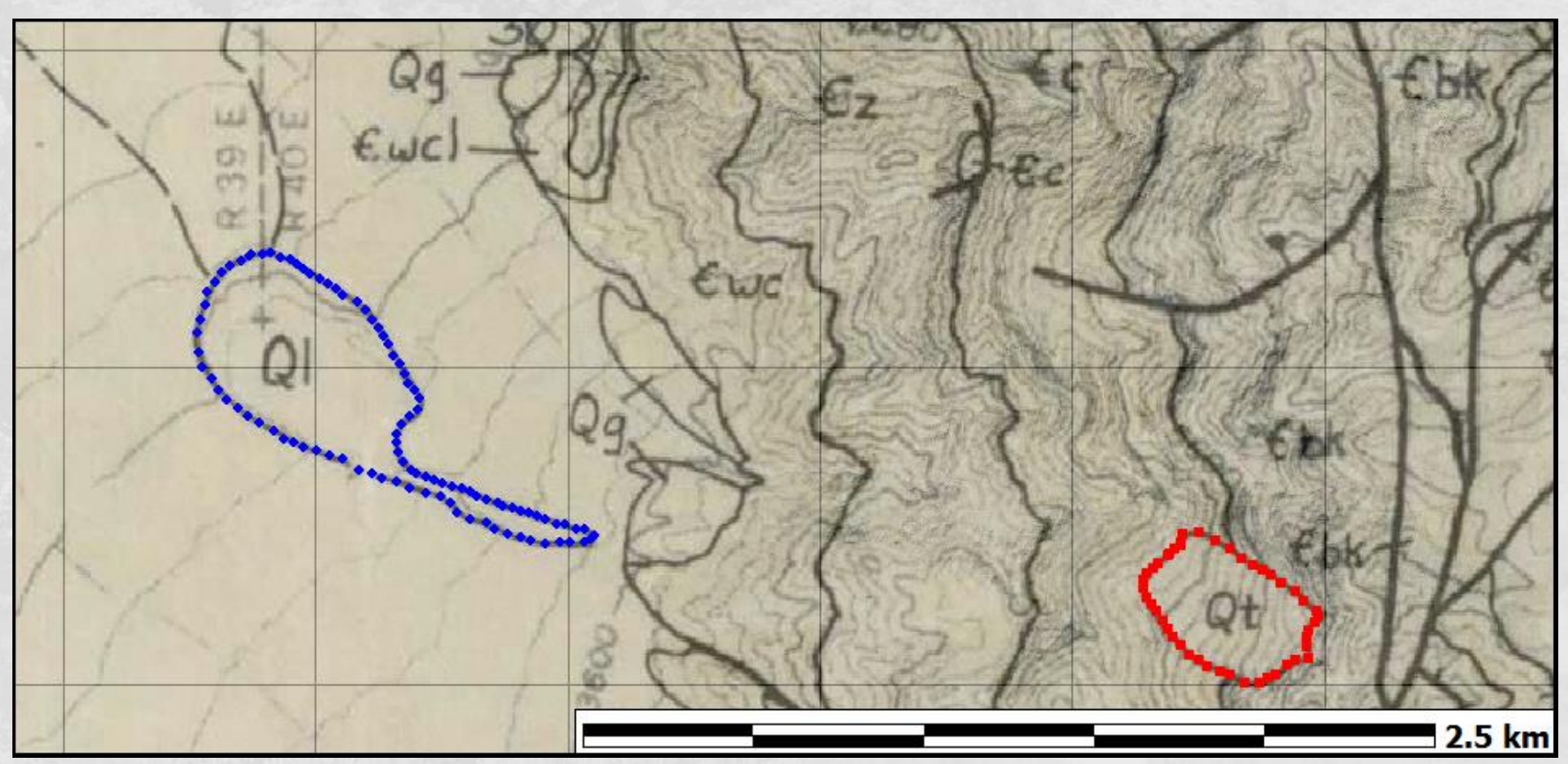









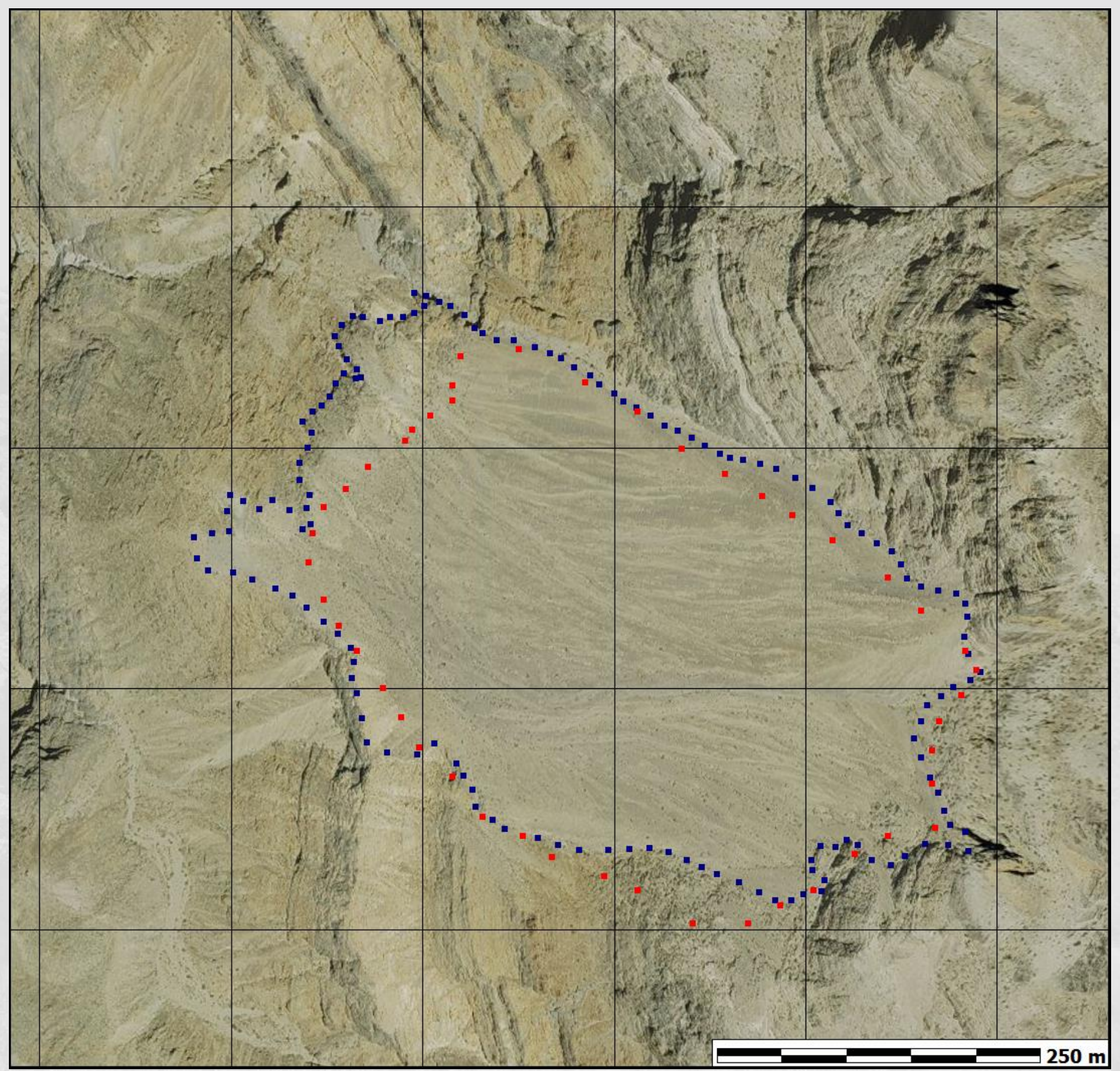



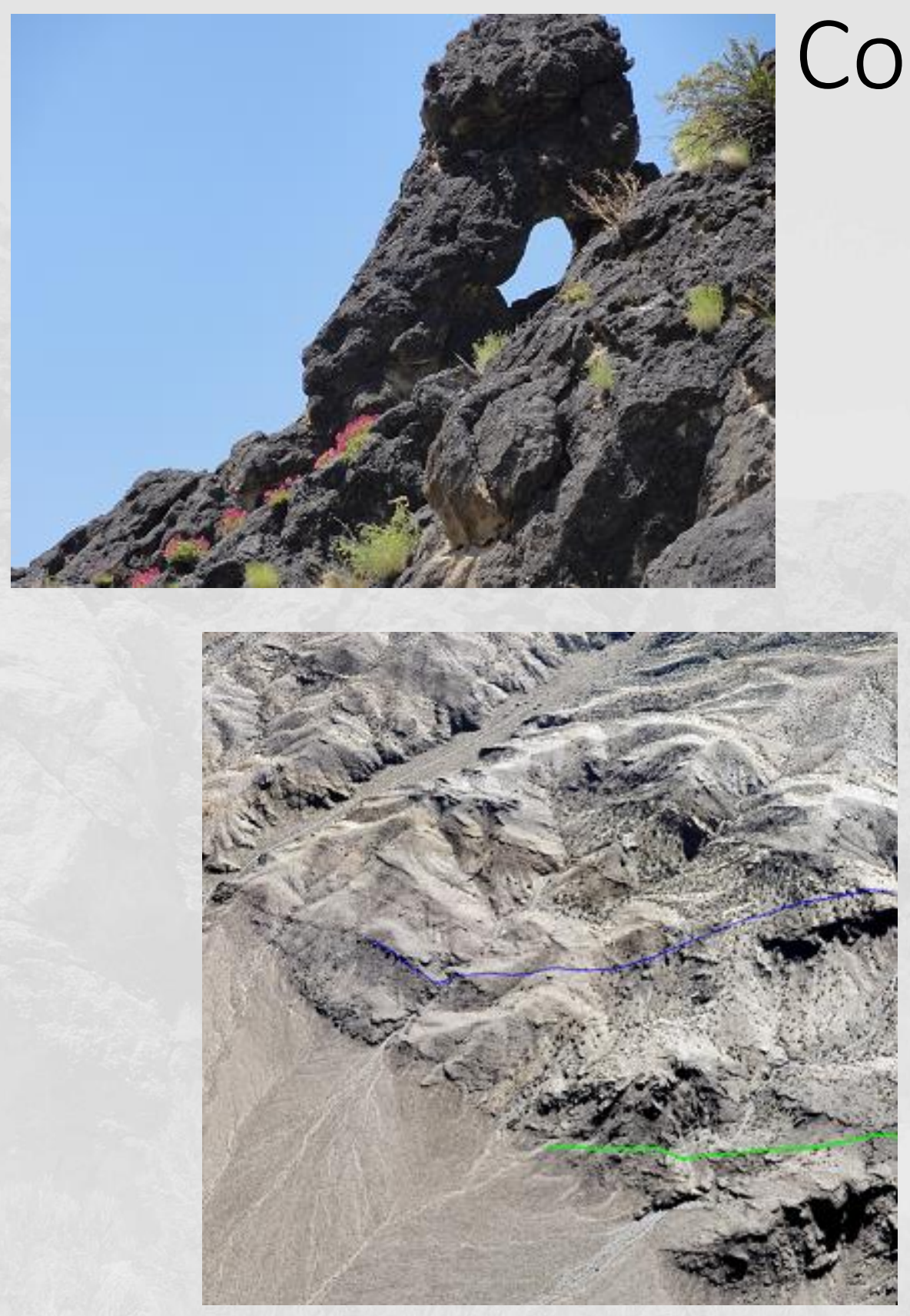

Conclusion-Free Data

- High resolution imagery and $10 \mathrm{~m}$ DEMs allow geometric tracing and modelling of faults

- $1 \mathrm{~m}$ DEMs from 3DEP increasingly available

- OpenTopography and other sources have $1 \mathrm{~m}$ DEMs, and point clouds to make your own with sub meter grid spacing

- Improved understanding of Hoodoo Hills Havoc 


\section{Following slides were not shown in Denver}




\section{Sheep Range References}

- French, D.E.., and Guth, P.L.., 2016, Megabreccias of the Sheep Range, Clark County, Nevada: 2016 Field Trip Guidebook, Nevada Petroleum and Geothermal Society, $50 \mathrm{p}$.

- Guth, P.L., 1980, Geology of the Sheep Range, Clark County, Nevada: unpublished PhD dissertation, Massachusetts Institute of Technology.

- Guth, P.L., 1981, Tertiary extension north of the Las Vegas Valley shear zone, Sheep and Desert Ranges, Clark County, Nevada: Geological Society of America Bulletin, vol.92, no.10, p.763-771.

- Guth, P.L., 1989, "Day 4. Tertiary extension in the Sheep Range Area, Northwestern Clark County, Nevada", p.33-39 in Wernicke, B.P., Snow, J.K., Axen, G.J., Burchfiel, B.C., Hodges, K.V., Walker, J.D., and Guth, P.L., 1989, Extensional tectonics in the Basin and Range Province between the Southern Sierra Nevada and the Colorado Plateau: Field Trip Guidebook T138, 28th International Geological Congress, American Geophysical Union, 80 p

- Guth, P.L., 1990, Superposed Mesozoic and Cenozoic deformation, Indian Springs Quadrangle: in Wernicke, B., ed., Basin and Range extensional tectonics near the latitude of Las Vegas, Geological Society of America Memoir 176, p.237-249.

- Guth, P.L., Schmidt, D.L., Deibert, J., and Yount, J., 1988, Tertiary extensional basins of northwestern Clark County: in Weide, D.L., and Faber, M.L., (eds.), This Extended Land, Geological Journeys in the southern Basin and Range, Geological Society of America, Cordilleran Section, Field Trip Guidebook, p.239-253. 


\section{Other References}

- Burchfiel, B. C. 1966. Tin Mountain landslide, southeastern California, and the origin of megabreccias. Geol. Soc. Amer. Bull. 77, pp. 95-100. T

- Shreve, R.L., 1968, The Blackhawk Landslide: Geological Society of America Special Paper 108, p. 1-48, doi:10.1130/SPE108-p1.

- Watkins, J., Scully, J.E.C., and Yin, A., 2012, Emplacement and subsequent modification of the Quaternary Eureka Valley landslide, eastern California: Geological Society of America Abstracts with Programs Vol. 44, No. 7, p.419.

- Watkins, J., Scully, J.E.C., Lawson, M., Rhodes, E., Yin, A. Emplacement Mechanisms and Evolution of the Long-runout Quaternary Eureka Valley Landslide in Eastern California. American Geophysical Union Fall Meeting, Abstract \#81953, December 2015.

- Wrucke, C.T., and Corbett, K.P., 1990, Geologic map of the Last Chance quadrangle, California and Nevada - 1990: U.S. Geological Survey OF-90-647-A, scale 1:62,500. 


\section{History of DEMs and 3D Problems}

- MICRODEM has handled since at least 1999

- Guth, P.L., 2014, Structural geology geometric operations in a GIS program and Google Earth: Geological Society of America Abstracts with Programs, vol.43, no.3, p.6. [Southeastern section meeting, Blacksburg VA, 10-11 April 2014]

- Guth, P.L., 2004, Computer manipulation of simple 3D structures: supplement, complement, or replace the field experience? Geological Society of America Abstracts with Programs, vol.36, no.5, p.157. [national meeting Denver, CO, Nov 2004]

- Other options on next two pages

- With standard data formats, programs can work together 


\section{Dynamic 3-Point Geological-Plane Solver}

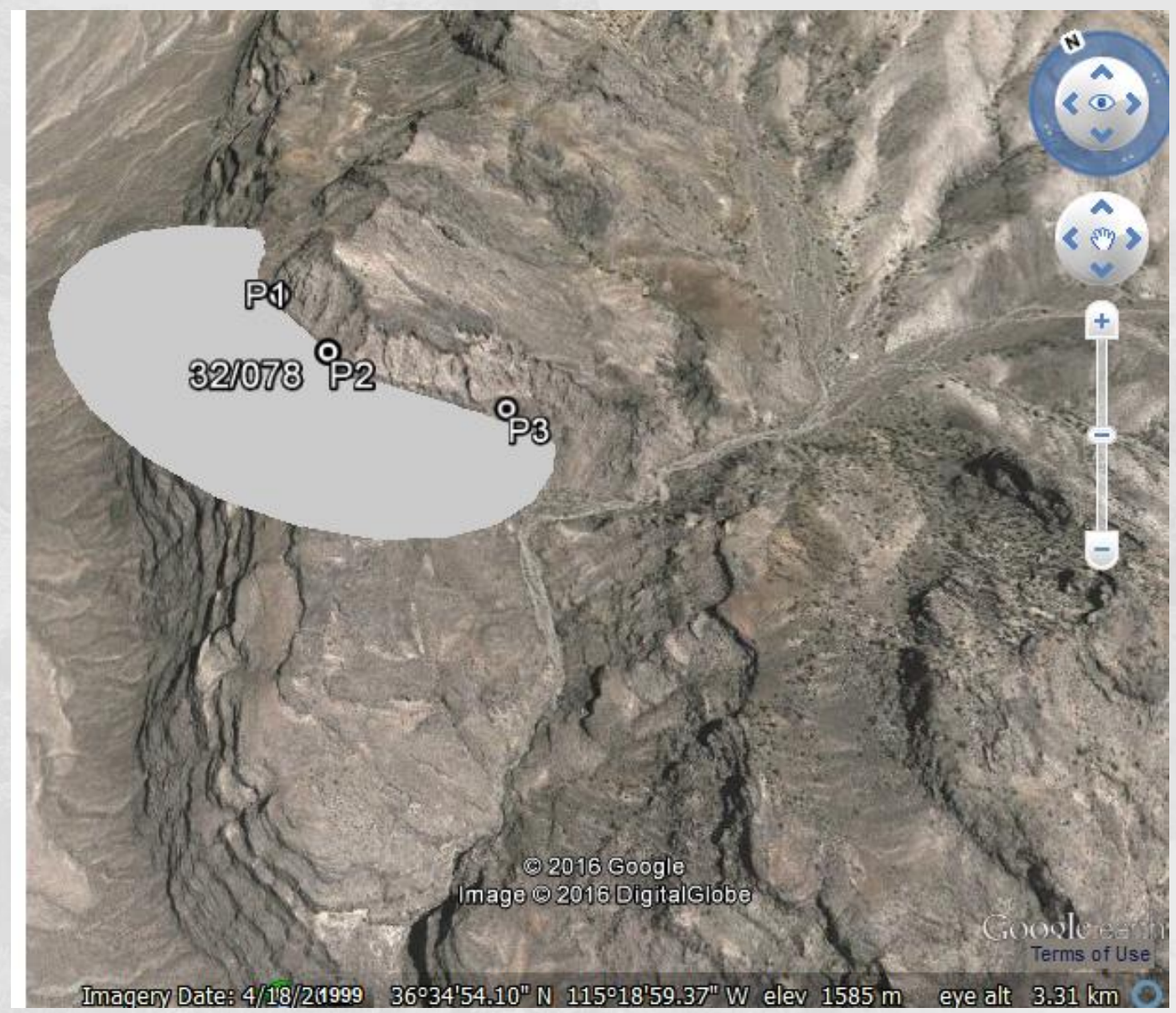

- By Jack Jamieson and Gregory C. Herman

- http://impacttectonics.org/ge oTools/3ppops.html

- May stop working imminently due to scheduled Google changes

- NASA World Wind 3-Point Problem Solver (Java) 


\section{GMDE (GeolMapDataExtractor)}

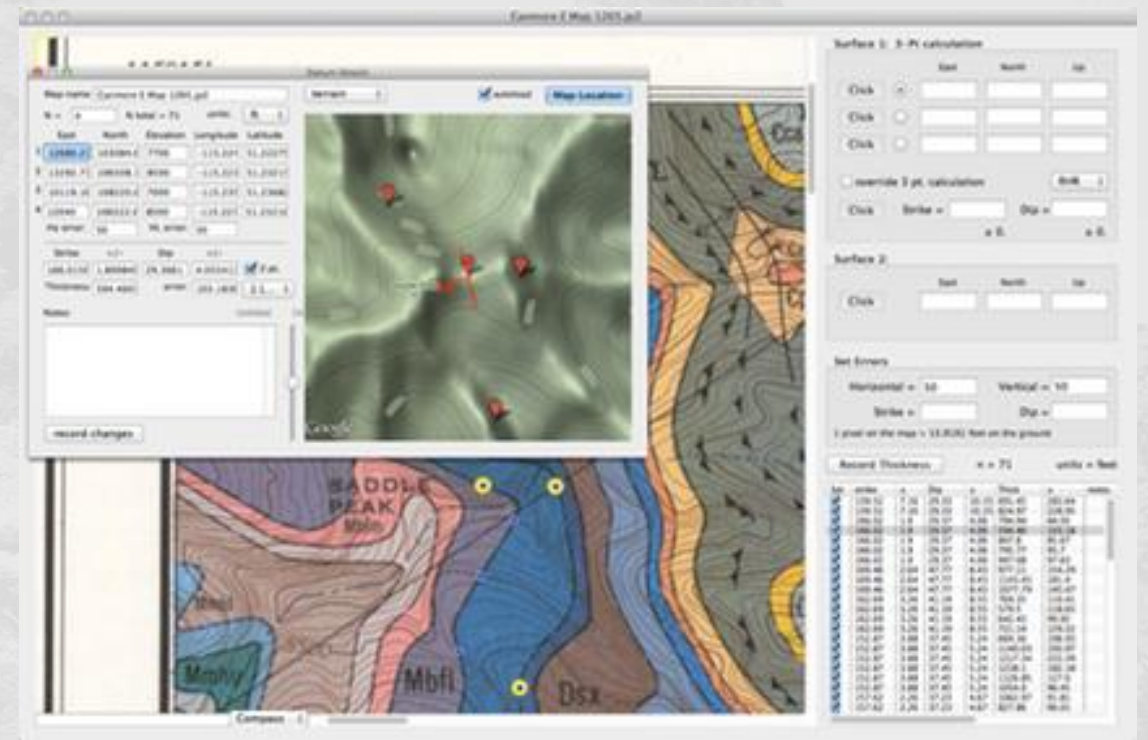

- http://www.geo.cornell .edu/geology/faculty/R WA/programs/strikedip thickness.html 